
CEsifo
WORKING
6586
2017
PAPERS

\title{
Activated History - The Case of the Turkish Sieges of Vienna
}

Christian Ochsner, Felix Roesel 


\section{Impressum:}

CESifo Working Papers

ISSN 2364-1428 (electronic version)

Publisher and distributor: Munich Society for the Promotion of Economic Research - CESifo $\mathrm{GmbH}$

The international platform of Ludwigs-Maximilians University's Center for Economic Studies and the ifo Institute

Poschingerstr. 5, 81679 Munich, Germany

Telephone +49 (o)89 2180-2740, Telefax +49 (o)89 2180-17845, email office@cesifo.de

Editors: Clemens Fuest, Oliver Falck, Jasmin Gröschl

www.cesifo-group.org/wp

An electronic version of the paper may be downloaded

- from the SSRN website: $\quad$ www.SSRN.com

- from the RePEc website: $\quad$ www.RePEc.org

- from the CESifo website: www.CESifo-group.org/wp 


\title{
Activated History - The Case of the Turkish Sieges of Vienna
}

\begin{abstract}
We study whether long-gone but activated history can shape social attitudes and behavior even after centuries. We exploit the case of the sieges of Vienna in 1529 and 1683, when Turkish troops pillaged individual municipalities across East Austria. In 2005, Austrian right-wing populists started to campaign against Turks and Muslims and explicitly referred to the Turkish sieges. We show that right-wing voting increased in once pillaged municipalities compared to non-pillaged municipalities after the campaigns were launched, but not before. The effects are substantial: Around one out of ten votes for the far-right in a once pillaged municipality is caused by salient history. We conclude that campaigns can act as tipping points and catalyze history in a nonlinear fashion.
\end{abstract}

JEL-Codes: D720, N430, N440, Z130.

Keywords: salience, persistence, right-wing populism, political campaigns, collective memory, Turkish sieges, Austria.

Christian Ochsner*
Ifo Institute - Leibniz Institute for
Economic Research
at the University of Munich
Dresden Branch
Einsteinstraße 3
Germany-01069 Dresden
ochsner@ifo.de

\author{
Felix Roesel \\ Ifo Institute - Leibniz Institute for \\ Economic Research \\ at the University of Munich \\ Dresden Branch \\ Einsteinstraße 3 \\ Germany - 01069 Dresden \\ roesel@ifo.de
}

*corresponding author

This version: July 26, 2017

We are grateful to Sascha O. Becker, James Fenske, Gunes Gokmen, Karoly Mike, Luigi Pascali, Steven Pfaff, Jared Rubin, Samuel Škoda, Marcel Thum, Hans-Joachim Voth, Bernd Wurpts, and Nikolaus Wolf as well as participants in the CAGE-AMES Workshop at the University of Warwick, the 10th CESifo Workshop on Political Economy in Dresden, the CGDE Workshop in Jena, the EPCS 2017 in Budapest, the IRES Graduate Workshop at Chapman University in Orange, the NOeG 2017 in Linz, the SSES 2017 in Lausanne and seminars at the Humboldt-Universitat zu Berlin and the Technische Universitat Dresden for helpful suggestions and comments. 
As I stand here today before this incredible crowd, this faithful nation, we can still hear those voices that echo through history.

\section{Introduction}

Politicians increasingly refer to history in order to evoke sentiments such as patriotism, unity, and identity. ${ }^{1}$ Myths and the collective memories are popular vehicles to convey political messages. Voters may then decide in light of sentiments, which potentially leads to judgment biases (Gennaioli and Shleifer 2010). For example, addressing history in speeches and campaigns uncovers long-gone historical circumstances which in turn may then translate into present-day outcomes after being invisible and irrelevant for centuries. Mullainathan (2002) provides a memory based model to predict judgements. The model suggests that myths or collective memories can lead to (over)reactions, especially when the current situation is perceived to parallel the historical narrative. Empirical evidence on this effect however is rare. It is unclear whether myths or collective memories are powerful enough to change voters' behavior.

Our study shows that the long-gone but arguably irrelevant past is able the shape political behavior if triggered by political campaigning. We exploit a unique historical setting where a local collective memory of long-gone experienced atrocities at the hands of foreign forces meet political campaigning that employs ethnic and religious stereotypes of the former enemy. After the conquest of Constantinople in 1453, the Turkish (Ottoman) ${ }^{2}$ Empire expanded its sphere of influence towards Central Europe. During the 16th and 17th centuries, Turkish troops marched

\footnotetext{
${ }^{1}$ Politicians use historic narratives both at home and abroad. US president Trump, for example, addressed Polish sentiments of resistance and their love of freedom in his speech in Warsaw on July 6, 2017. Trumps presidential campaign slogan "Make America great again" also refers to the apparently gone strength of the US. In Europe, populist politicians recall historical myths in order to gain electoral support. Hungary's president Viktor Orbán, among others, uses the country's historic legacy to state that Hungary once again have to protect Europe from tyranny from the East.

${ }^{2}$ We refer to the terms "Turkish sieges of Vienna," "Turkish army" and "Turks" according to the normal practices of historiography about the sieges of Vienna. The term "Ottoman" is seldom or never used in relation to the sieges.
} 
against the Habsburg capital of Vienna several times. There were two major sieges of Vienna in 1529 (Siege I), and 1683 (Siege II). Prior to and during the sieges of Vienna, however, Turkish troops undertook forays in the surrounding areas. They pillaged and plundered individual villages and raped, killed and kidnapped local residents. As a result of these Turkish atrocities, whole regions were razed and substantially depopulated. "Visual history" (for example, historical buildings, memorials, and coats of arms), rituals and the school curriculum transfer these brutal events to the present day.

We link records of Turkish atrocities during the sieges to vote shares in national elections for the right-wing populist Freedom Party of Austria (Freiheitliche Partei Österreich, FPÖ). In 2005, the FPÖ started to campaign against Turks and Muslims and to refer explicitly to "their" vicious crimes during the Turkish sieges of Vienna. We show that right-wing voting increases in once pillaged East Austrian municipalities in comparison to non-pillaged municipalities over the course of the campaigns. By contrast, vote shares did not differ among the pillaged and nonpillaged municipalities in the decades prior to 2005. Even cross-sectional "eyeball econometrics" yield remarkable similarities in records of Turkish atrocities (Figure 1, left-hand side) and the absolute change in vote shares for the right-wing populist FPÖ between the last national election prior to the start of the campaigns in 2002 and 2013 (right-hand side).

Anecdotal evidence also implies a direct link between campaigning and voting intention. Comments in various internet forums are an excellent case in point. ${ }^{3}$ In 2008 , for example, one visitor reports on his change in mind towards the Austrian far right:

\footnotetext{
${ }^{3}$ We cite comment no. 29 by The Penguin for the article "Die österreichische Türkeiverschwörung" on the rightwing populist website PI News, https://www.pi-news.net/2008/08/die-oesterreichische-tuerkeiverschwoerung/; comment no. 79 by "no no-go" for the article "Lehrplanänderung aus Rücksicht auf Türken," https://www.pinews.net/2009/06/lehrplanaenderung-aus-ruecksicht-auf-tuerken/; and the comment by jennyundchris for the article "Endlich - Strache kandidiert für Wiener Bürgermeister," https://webheimat.at/forum/Politik/Endlich-Strachekandidiert-fuer-Wiener-Buergermeister.html.
} 
"To be honest, I have never voted FPÖ in my lifetime before. Never. However, Strache [the FPÖ leader] is getting more and more attractive. [...] Conditions as of 1683 ... Okay! I will prepare my guns and move to the Löbelbastei! [Sic - the Löwelbastei was the main target of the Turkish attacks on Vienna in 1683.]"

Another user is outraged about a debate in 2009 over whether and how to teach about the Turkish sieges of Vienna in the school curriculum. He writes:

"I am really not a sympathizer of the FPÖ. But before I give my vote to the dogooder I will vote for the 'lesser evil'. Rather 'right' than moronic!'

Another user in 2009 directly adopts the FPÖ's anti-Turkish campaigns to express her discontent about Turkish foreigners in the following way:

\section{"[...] I do not feel comfortable anymore. It seems to me like the Third Turkish Siege of Vienna. [...] My husband and I are tired of this policy - we vote for HC [HC refers to the leader of the FPÖ, Heinz-Christian Strache]."}

We show that these anecdotes of a shift in voting intention are particularly pronounced in municipalities with direct exposure to Turkish atrocities during the sieges of Vienna. Anti-Turkish campaigning increases FPÖ vote shares by 1.1 to 1.7 percentage points in once pillaged municipalities, depending on the specification. This translates to a "persuasion rate" of approximately 7 to 11 percent when we compare pillaged to non-pillaged municipalities and account for precampaigning differences. ${ }^{4}$ Thus, at least 1 of 14 votes for the far right in a once pillaged municipality is caused by campaigning that activated local history. The persuasion rate is even larger when we account for potential measurement errors and spill-overs between adjacent municipalities using a spatial fuzzy regression discontinuity (RD) approach. Our results hold under various robustness tests. The vote shares of other Austrian far-right populist parties that do not

\footnotetext{
${ }^{4}$ We define the persuasion rate as the share of additional FPÖ voters that have been attracted by campaigning that activated local history. We compute the persuasion rate by dividing the differences in vote shares among pillaged and non-pillaged municipalities after the start of the campaign by the average vote shares during the campaigning period after 2005 for pillaged municipalities (16 percent). Campaigning increased the vote shares for the FPÖ in pillaged municipalities by approximately 1.1 to 1.7 percentage points, depending on the model (difference-indifferences model). Thus, $1.1 / 16=6.9$ and $1.7 / 16=10.6$ percentage points, respectively.
} 
employ anti-Turkish campaigns do not differ among pillaged and non-pillaged municipalities.

Additionally, the exposure to pillages by foreign forces other than Turkish troops, e.g., Hussite, Hungarian, Swedish, or French forces, does not explain right-wing voting. Heterogeneity analyses indicate that activation effects are more pronounced in small and more rural municipalities.

FIGURE 1. TURKISH PILLAGES AND FPÖ VOTE SHARES IN EAST AUSTRIA

Turkish pillages $(1529 / 1683)$

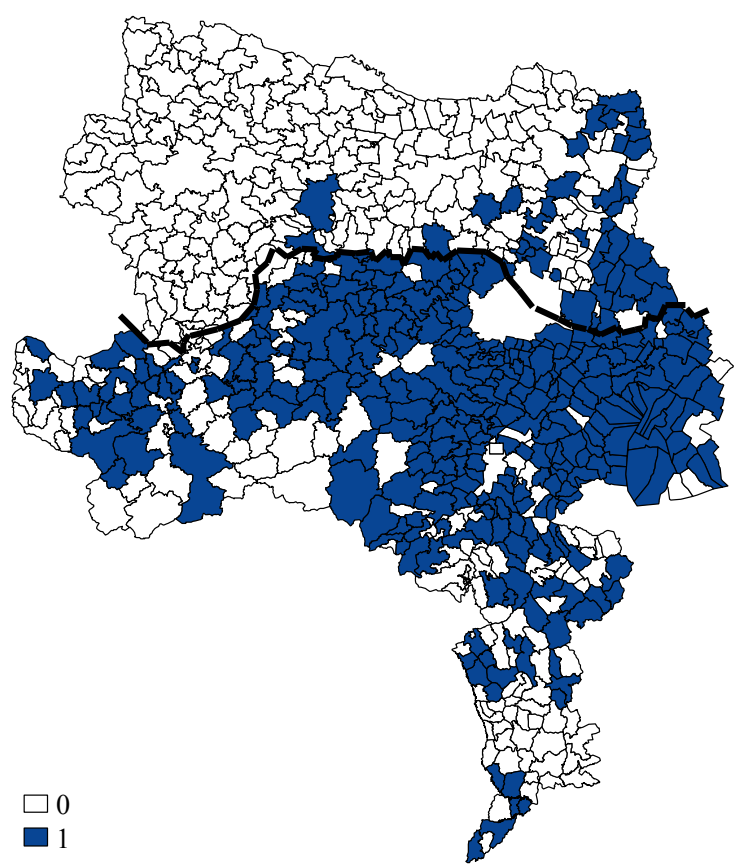

Change in FPÖ vote shares from 2002 to 2013

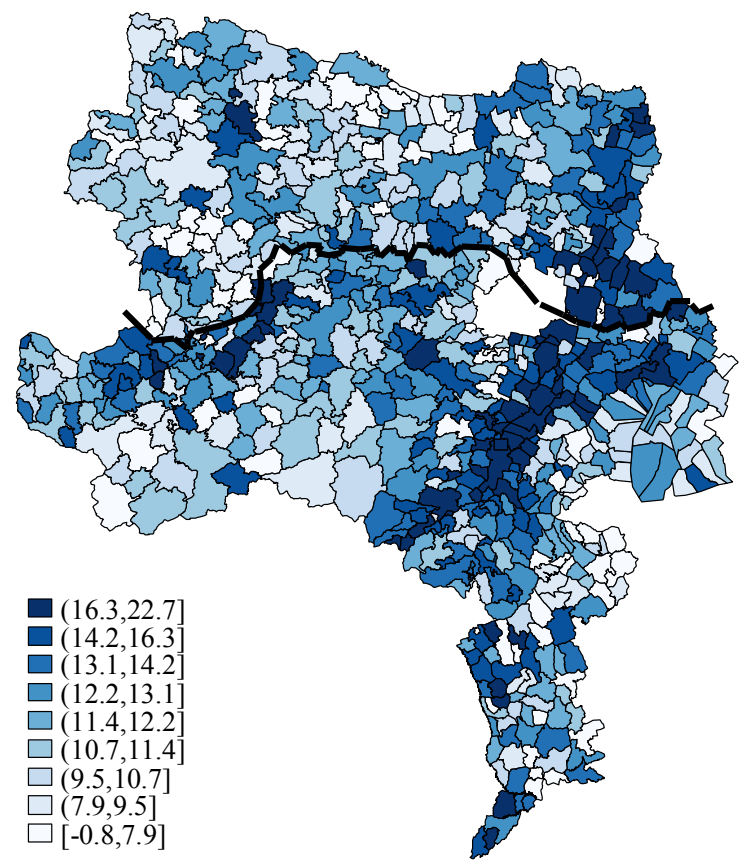

Notes: The maps show 690 municipalities in East Austria (federal states of Burgenland and Lower Austria). The bold line represents the Danube River. The left-hand map shows the geography of the municipalities pillaged by Turkish forces (see Section 4.1 and the supplementary material for a description). The dark-shaded municipalities were pillaged either in Siege I (1529/1532) and/or Siege II (1663-1683). The right-hand map shows the absolute change in vote shares for the right-wing populist FPÖ from the 2002 to the 2013 national election.

Our study contributes to the literature in several ways. First, no study has yet shown that longgone historical events can appear in contemporary socio-economic figures after having been apparently irrelevant for centuries. Two related studies provide evidence in the case of more recent events. Fouka and Voth (2016) show a relative decline in German car sales in Greek regions that experienced WWII German Wehrmacht reprisals after 2010, when tensions between Germany and Greece increased over the course of the Greek sovereign debt crisis. Fis- 
man, Hamao and Yongxiang (2014) link changes in stock markets to the cooling of Sino-Japanese relations in 2005, when severe disputes arose over Japanese crimes in occupied China in the 1940s. These studies show that historical events may materialize some 60 or 65 years later. We, by contrast, find that historical events from even 300 to 500 years ago can be activated in the present day.

Second, we show substantial impacts of political campaigning against ethnic and religious minority groups. Previous studies use differences in media exposure to analyze the effects of political campaigns. These are, e.g., the arguably exogenous availability of specific TV channels (Gentzkow 2006, DellaVigna and Kaplan 2007, Enikolopov, Petrova and Zhuravskaya 2011, Da Silveira and De Mello 2011, Gerber et al. 2011), radio reception (DellaVigna et al. 2014, Adena et al. 2015) or newspapers (Gerber, Karlan and Bergan 2009, Gentzkow, Shapiro and Sinkinson 2011). Madestam et al. (2013) use weather conditions to show that exposure to political protests influences election outcomes, and Kendall, Nannicini and Trebbi (2015) randomize information about candidates' valence and ideology, which in turn affect voters' behavior and beliefs. We show that political campaigns are likely to shape perceptions about the long-gone past, which was irrelevant for every one's life for decades or even centuries. History thus has an inherent salience effect. ${ }^{5}$ Voters in formerly pillaged municipalities seem to treat the campaign information differently and are in turn more willing to vote for the extreme right. This finding suggests that voters are sensitive to information in the way mentioned by Kahneman and Tversky (1982) or Gennaioli and Shleifer (2010) and applied to a (collective) remembrance by Mullainathan (2002).

\footnotetext{
${ }^{5}$ Bordalo, Gennaioli and Shleifer (2017) provide a theory of how signals lead to an over- or underreaction based on past experiences. Empirical studies that document overreaction focus on, e.g., the marking of excise taxes (Chetty, Looney and Kroft 2009). Underreaction is found in ranking information (e.g., Pope 2009) or financial news (e.g., DellaVigna and Pollet 2009).
} 
Third, our study contributes to an increasing number of studies that link long-gone historical events or circumstances to present-day socio-cultural attitudes. Long-term persistence is well documented for anti-Semitism (Voigtländer and Voth 2012, 2015), social trust and development (Nunn and Wantchekon 2011) and trust and corruption in bureaucracy (Becker et al. 2016). Other studies examine historical institutions to explain differences in current socio-economic variables (e.g., Tabellini 2008a, 2008b, 2010, Guiso, Sapienza and Zingales 2016). ${ }^{6}$ However, prior studies do not analyze whether historical events shape norms permanently, i.e., in a linear fashion, or whether history occasionally appears from time to time, triggered by activation mechanisms. So far, researchers seem to favor a theory of linear evolution. Studies argue, for example, that the attitudes and preferences of the East German population will slowly but steadily converge towards those of their Western German counterpart (Ockenfels and Weimann 1999, Alesina and Fuchs-Schündeln 2007, Brosig-Koch et al. 2011). Our findings provide evidence that societies can also evolve and interact in a non-linear fashion. Campaigns may uncover differences in local history. We thus provide empirical evidence for tipping points in the evolution of social norms and social behavior that have been described in narrative and theoretical studies (e.g., Schelling 1978, Young 2015).

Fourth, we provide evidence that the electoral support for far-right political parties has deep historical roots. Few prior studies have addressed this issue so far. Voigtländer and Voth (2012) link anti-Semitism in the 14th century to German Nazi party votes in the 1920s. Funke, Schularick and Trebesch (2016) show that economic and financial crises increase the likelihood of

\footnotetext{
${ }^{6}$ Persistence can be observed in economic variables as well as socio-cultural variables. For instance, Hall and Jones (1999), Glaeser and Shleifer (2002), Nunn (2008), Dell (2010), Acemoglu, Hassan, and Robinson (2011), Hornbeck and Naidu (2014), and Oto-Peralías and Romero-Ávila (2017) link historical shocks and events to current economic inequality. Further, economic variables in developing countries seem to be highly influenced by the past activities of Europeans. These are, e.g., colonialization (Acemoglu, Johnson, and Robinson 2001) or missionary activities (Nunn 2010, Caicedo 2014). Spolaore and Wacziarg (2013) argue that economic development is affected by traits via the intergenerational transmission of social norms. However, current figures in economic variables are more easily linked with the past via a persistent channel - mainly due to physical capital in place that persists.
} 
the permanent representation of extreme right-wing parties in national parliaments. The results of Ochsner and Roesel (2016) indicate that post-WWII Nazi migration explains local differences in right-wing voting even in recent elections. Most studies on populist right-wing movements, however, neglect the role of history or past experience. These studies link immigration to right-wing attitudes with respect to labor market conditions (Scheve and Slaughter 2001; Mayda 2006), welfare state concerns (Dustmann and Preston 2007, Hanson, Scheve and Slaughter 2007, Arzheimer 2009, Facchini and Mayda 2009, Card, Dustmann and Preston 2012), criminality (Rydgren 2008), or the individual values and beliefs of voters (Hainmueller and Hiscox 2007, 2010, Hainmueller, Hiscox and Margalit 2015) to explain the rise of the far right. Arzheimer (2017) provides a rich overview. Other studies link contact with foreigners (e.g., Schindler and Westcott 2015; Halla, Wagner and Zweimüller 2016; Steinmayr 2016) or social capital (Rydgren 2011; Satyanath, Voigtländer and Voth 2017) to vote shares for rightwing parties. Our study bridges the two strands of studies in the past and present determinants of right-wing voting.

We will proceed as follows. In the next section, we outline the sieges of Vienna and illustrate how these events have survived in the local "visual history" and collective local memory. Section 3 describes the anti-Turkish campaigns of the Freedom Party of Austria (FPÖ) from 2005 onwards. Section 4 introduces our dataset and describes our identification strategy, which is a difference-in-differences estimation that we will later extend to a spatial fuzzy RD approach. Section 5 shows the results, and Section 6 conducts robustness tests. In Section 7, we investigate the mechanism at work. Section 8 offers concluding remarks. 


\section{The Turkish sieges of Vienna}

\subsection{Turkish atrocities in 16th-and 17th-century Austria}

The Turkish conquest of Constantinople in the 15th century was a turning point in European history. For the ensuing two and a half centuries, Turkish military expeditions menaced Eastern and Central Europe (Magocsi 2002). East Austria, i.e., the contemporary federal states of Lower Austria, Vienna and Burgenland, was the most northerly target of Turkish military expeditions that lasted until the late 17th century. Almost all the Turkish attacks in Austria occurred in these three federal states. This region was the most affected because of its geographic proximity to the Habsburg capital city of Vienna. Mountain ranges isolate East Austria from other Austrian regions in the southwest. ${ }^{7}$ Turks did not settle in East Austria; Turkish troops marched up and completely withdrew from the region within a couple of weeks (Siege I) or within three months (Siege II).

The Turkish army and its auxiliary troops marched several times against East Austria; the main target was the Habsburg capital city of Vienna. Figure 2 depicts the four Turkish expeditions towards East Austria. The maps illustrate the movements of the official Turkish troops on their way to Vienna (solid arrows) and show the sites of important battles where Turkish troops were stopped (stars). The maps also depict East Austrian regions that were afflicted by auxiliary troops (dashed arrows). These auxiliary troops, the so-called Akıncl or Tatars, acted as vanguards with their own military leaders and consisted mainly of rural Turkish men. ${ }^{8}$ In comparison to the official Turkish army, the Akıncl and Tatars were not in the Ottoman Empire's pay and thus relied heavily on finding rich prey. According to Gerhartl (1981), this was the main reason that the auxiliary troops were even more harmful and brutal than the official Turkish

\footnotetext{
${ }^{7}$ Some minor attacks also occurred in South Austria during the Turkish dominance over the Balkans and in presentday Upper Austria in 1532 (Gerhartl 1981). Note that the attacks in South Austria are not associated with the Turkish sieges of Vienna.

${ }^{8}$ Note that some auxiliary troops also consisted of Christian Hungarian troops that were allies of the Turks.
} 
forces. The historical sources and literature refer especially to the Akıncl as "racer and burner" (Renner und Brenner), which indicates their speed and destructive rage.

The Turkish advance towards Central Europe became apparent in 1521, when first Belgrade and subsequently Budapest in Hungary was captured by Turkish troops (Magocsi 2002). Starting in Budapest, the Turkish troops followed the Danube River on their way to Vienna. The first siege of Vienna occurred in the fall of 1529. After three weeks of unsuccessful attacks, Turkish troops and the pillaging auxiliary troops withdraw from Vienna and its surroundings and moved back towards Hungary (Hummelberger 1983). ${ }^{9}$ The Habsburg army and its allies did not want to follow the Turkish troops to take revenge. This allowed the Turks to reorganize and to prepare for a second attack in 1532. On their way to Vienna, the official Turkish troops were held back due to the successful resistance of the city of Köszeg in Hungary. ${ }^{10}$ Approximately 50,000 Akıncl, however, were already on their way towards the northwest. Villages and inhabitants south of the Danube River were heavily affected by pillages, killings and kidnappings. The trail of destruction was much more severe than in 1529 (Gerhartl 1981). The events of 1529 and 1532 are commonly labeled "Siege I of Vienna".

\footnotetext{
${ }^{9}$ Gutkas (1973) reports a number of approximately 30,000 Akıncl and the estimated number of direct victims of pillaging by the Akıncı in 1529 at approximately 100,000 in Lower Austria only. However, direct deaths from violent attacks during early modernity might be undervalued owing to total loss of population. As Tallett (1992) notes, most civilian fatalities during wars occurred because of poor nutrition or diseases introduced by the enemies. ${ }^{10}$ The official Turkish troops withdrew from Köszeg towards the southeast. This caused additional devastation in some parts of Southeast Austria (Gerhartl 1981).
} 


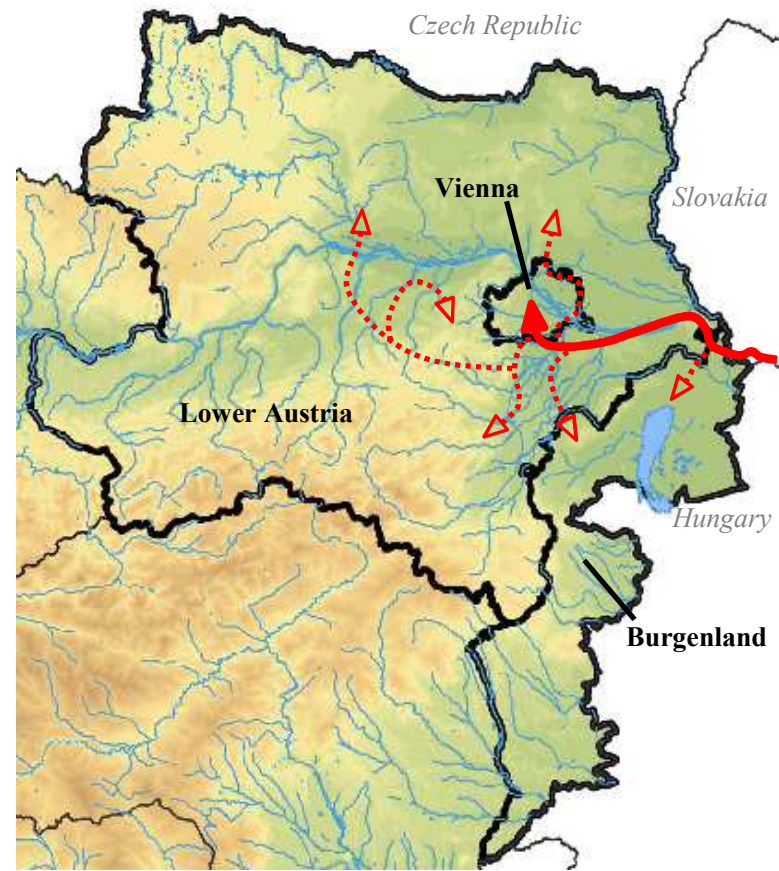

$1663 / 1664$

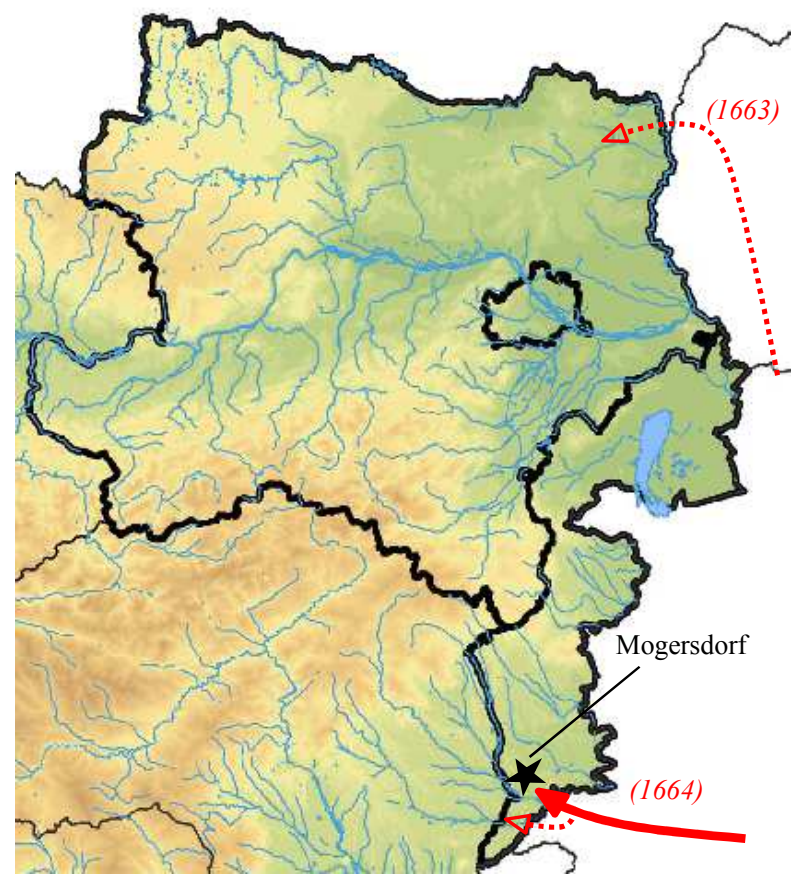

Turkish Army

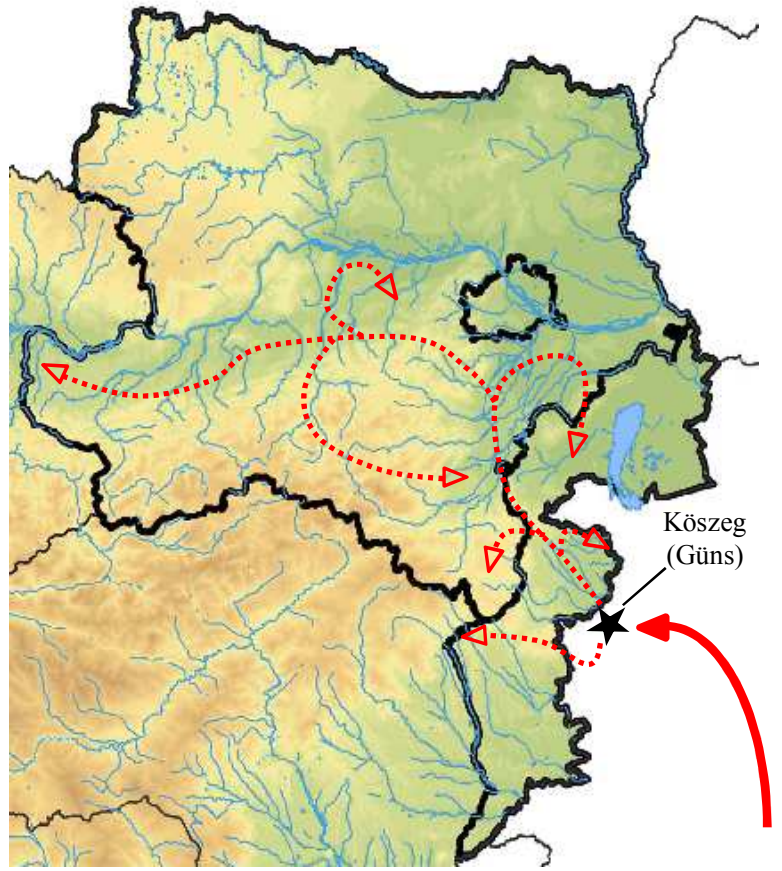

1683

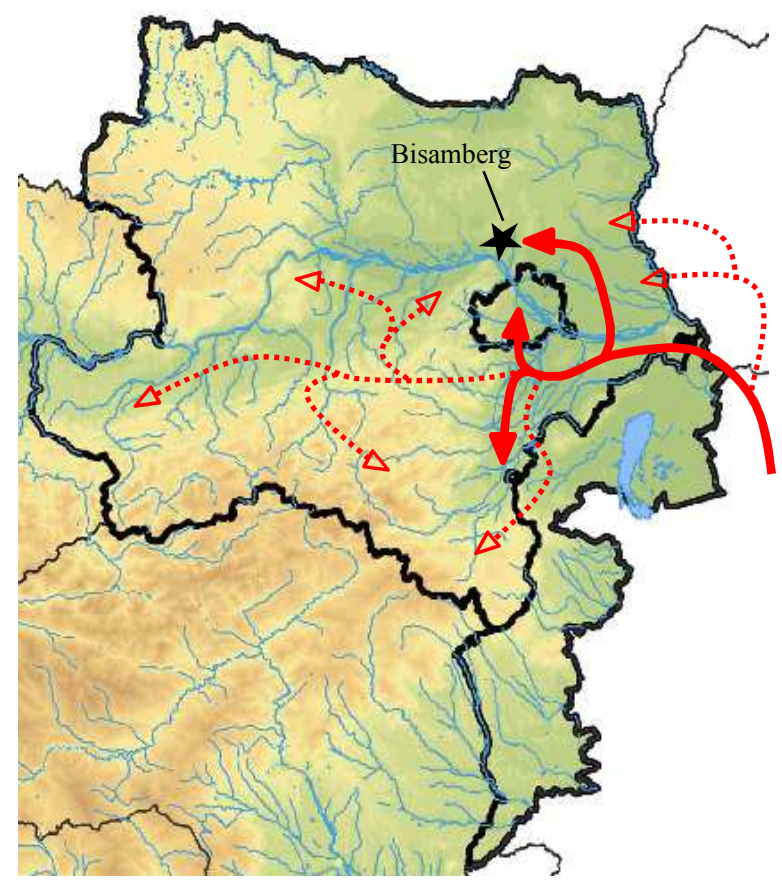

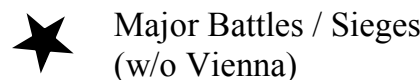

Notes: The maps show the invasions of the Turkish army and auxiliary troops (Akıncl, Tatars) in East Austria during the 16th and 17 th centuries. Red bold lines show the route of the Turkish army on its way to Vienna. Dotted red lines show the route of the pillaging auxiliary troops through East Austria. Important battles and sieges (without the sieges of Vienna) are indicated with stars. The topographic map shows Austria. All internal and external borders represent the current territorial status. Sources: Gutkas (1973), Gerhartl (1981, 1983), Hummelberger (1983), Magocsi (2002). 
The Turkish military threat was averted for more than a century after Siege I. In the mid-17th century, however, the Ottoman Empire revived its ambition to expand towards Central Europe. The comeback of the Turks became visible in East Austria in the 1660s when Turkish auxiliary troops attacked municipalities in the northeast part of Lower Austria and Turkish troops fought a major battle in southern Burgenland (the Battle of Mogersdorf). In 1683, the Turkish army, again accompanied by auxiliary troops, started to march against Vienna. The army besieged Vienna for about two months (Siege II of Vienna), and Vienna was nearly ready to capitulate. Once again, pillaging auxiliary troops roamed the areas surrounding Vienna. In a last-minute military operation, allied troops of Austria, Poland, Germany and France were able to stop the Turkish expansion north of the Danube River (the Battle of Bisamberg) and then to force back the Turkish besiegers of Vienna (Gerhartl 1983, Stoye 2007). ${ }^{11}$ This defeat had long-term consequences for the Ottoman Empire. As a main result, the Habsburg Empire regained control of Hungary. The Turkish threat was ultimately banned.

\subsection{Collective memory of the sieges}

According to Assmann (1988), past events are remembered in the present day via cultural formation (e.g., rituals, texts, visual memories such as memorials, historical monuments or illustrations etc.) or institutionalized communication (e.g., school curricula or anniversary commemorations organized by state or church authorities). Halbwachs (1985) argues that a collective memory is always spatially embedded. In the following section, we show that there is a vital local collective memory in the East Austrian regions that were exposed to Turkish violence during the 16 th and 17 th centuries.

\footnotetext{
${ }^{11}$ Note that the Battle of Bisamberg represents the end of the expansion of Turkish troops towards the west to the north of the Danube River. Later, we will use this regional variation along the Danube River to identify our spatial fuzzy regression discontinuity framework.
} 
Symbols of the cultural formation of the Turkish attacks are fairly common in East Austria, as $12.5 \%$ of all East Austrian municipalities have a direct visual memorial as a reminder of the Turkish presence or atrocities. History is literally visible in official municipal coats of arms, monuments, or stained-glass church windows. These images remind the inhabitants of the Turkish atrocities by showing the destructive Turkish troops, burning houses, fleeing people, or Turkish swords. Figure 3 shows a sample of such visual memories. First, the emblem of the municipal coat of arms of the municipality of Markt Piesting shows two Turkish swords, a burning tower and the date 1529 (Siege I). Second, wayside shrines, the so-called "Türkenkreuze" or "Tükenmarterl" (Turkish crosses), remind the local population of the Turkish slaughters. Third, the cruelty of the Turks is illustrated in pictures. The church window in the municipality of Perchtoldsdorf, for example, shows how the Turks overran the town and decapitated its residents. Further examples of visual memories are shown in Figure 8. These are ruins of towns that were completely destroyed and never rebuilt; plaques that commemorate the people killed; structures such as towers, walls or gates (e.g., Türkenmauer (Turkish wall), Türkenturm (Turkish tower)), and streets, places, fields or caves that are named in remembrance of the Turkish sieges (e.g., Türkenstrasse (Turkish Street), Türkenplatz (Turkish Square), Türkenloch (Turkish cave)). ${ }^{12}$ Local legends, rituals and texts also link the past to the present day. For instance, the village of Katzelsdorf(“Katz" means cat) cultivates the legend that the village was named after the sole survivor of the Turkish attacks - a cat. Rituals that are reminders of the Turkish threat occasionally occur in the municipalities of Perchtoldsdorf, Waidhofen/Ybbs and Hernals (Dallinger 2013, Hadler 2013). Finally, municipal chronicles as well as church chronicles contain reports of the Turkish attacks. These chronicles often perpetuate stereotypes of Turks and Muslims such as their propensity to violence or aim to subdue Western society. In

\footnotetext{
${ }^{12}$ Note that field names, cave names and wayside shrines are not unique to commemorating the Turkish sieges. In regions of the Swedish invasion in the 17th century or the Napoleonic invasion in the early 19th century, there are also so-called "Schwedenkreuze" (Swedish crosses) or "Franzosenkreuze" (French crosses) as well as French or Swedish gates and walls.
} 
sum, these labels and rituals form local culture and make history visible in the formerly affected municipalities every day.

\section{FIGURE 3. HiSTORICAL MEMORIALS (EXAMPLES)}

A: Official symbols (municipal coat of arms)
B: "Türkenmarterl" (wayside crosses evoking the pillages)

\section{C: Churches (church window showing a Turkish attack)}
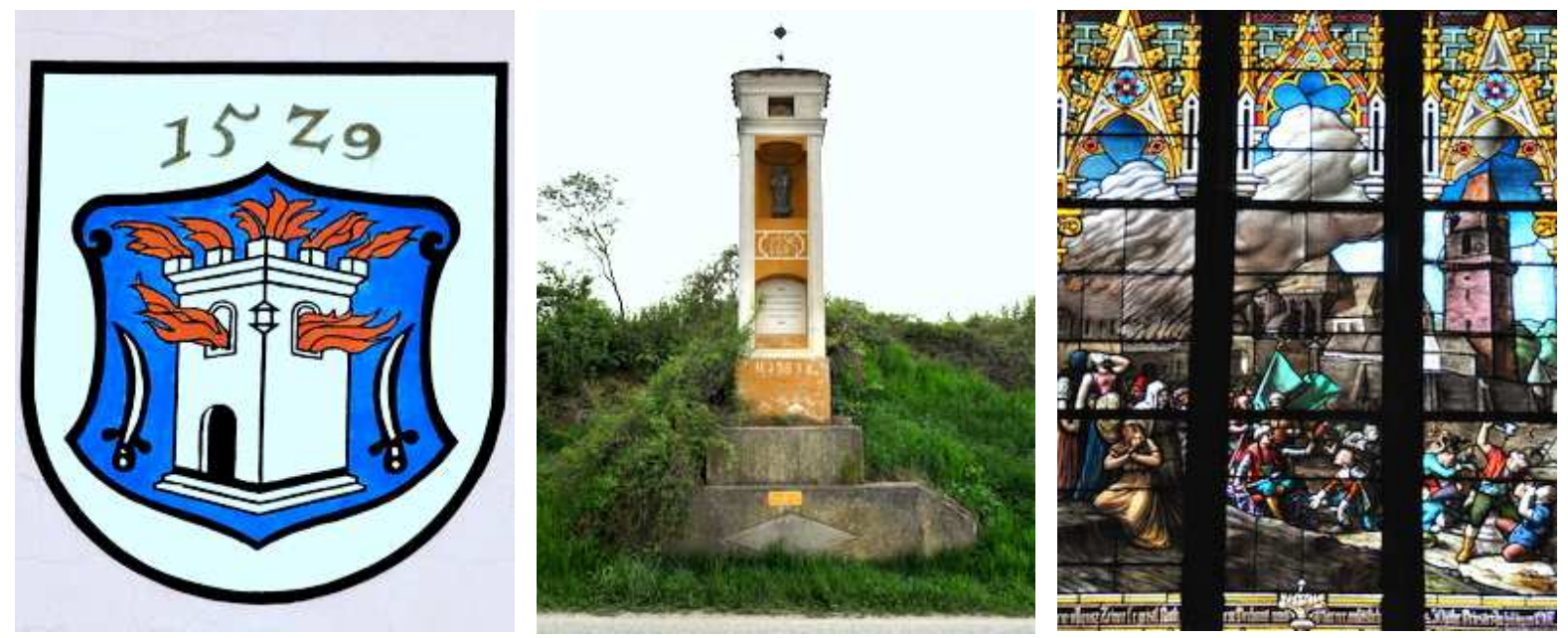

Notes: The pictures show examples of visual memories in Lower Austria and Burgenland. Figure A shows the municipal coat of arms of the municipality of Markt Piesting. The emblem contains two Turkish swords, a burning tower and the date 1529 (Siege I of Vienna). Figure B shows a wayside cross in the municipality of Inzersdorf ob der Traisen. The cross evokes the atrocities of 1683 (installation in 1687). The inscription reads, "Constructed by people who escaped the Turks." Figure C shows a church window in the municipality of Perchtoldsdorf. The window commemorates the pillages during Siege II. It depicts the Turkish attack, burning houses, escaping people and the massacre of the population. Further examples of visual memorials are given in Figure 8 in the supplementary material. Photos: Christian Ochsner.

Another transmission channel of cultural memories is institutionalized communication. Austrian schoolbooks and school curricula address the Turkish sieges of Vienna (Gingrich 2003). Pupils in East Austria undertake historical tours and visit memorials. Witzeling (2013) states that teachers in East Austria share their local (sometimes subjective) knowledge of the sieges with their classes. This transmission is said to be less pronounced in other Austrian regions. Still, many teachers currently consider the Turkish sieges of Vienna a Muslim attempt to enlarge the sphere of the Islamic religion (Witzeling 2013). Other historical interpretations of the sieges, perceiving them, for example, as power politics or a simple territorial dispute between two major powers of the past, are often neglected. Another form of institutionalized communication in addition to school curricula are celebrations of anniversaries that are organized by 
either the state or the church. The sieges of Vienna, especially Siege II of 1683, were commemorated in 1783, 1883, 1933, and 1983. These events go hand in hand with increased publicity about the past. For instance, the number of newspaper articles that addressed the Turkish siege of Vienna skyrocketed in 1983, whereas only a few media articles addressed this issue in the decades before (Pfeifer 2013).

\section{Anti-Turkish campaigns of right-wing populists}

The Freedom Party of Austria (Freiheitliche Partei Österreich, FPÖ) is the main right-wing party in post-WWII Austria. ${ }^{13}$ During a change in party leadership in 2005, the FPÖ strengthened its anti-immigration profile. Xenophobia has been a political issue since the early 1990s. In contrast to the previous decades, however, anti-Turkish and anti-Muslim campaigning became a main element of the party's propaganda strategy after 2005. The shift towards antiTurkish and anti-Muslim propaganda is illustrated in Figure 4. The figure offers a content analysis of FPÖ poster slogans from 1949 to 2008, based on the election campaign poster collection of the Austrian National Library (ANL). In total, 1,436 FPÖ posters can be found through the ANL search command. ${ }^{14}$ In the direct aftermath of WWII, when the FPÖ and its predecessor (Verband der Unabhängigen, VdU) was led by former leading members of the German Nazi party (NSDAP) and the Waffen-SS (see, e.g., Staeuber 1974), the majority of the poster slogans raged against other political parties or stated clear economic or Austrian internal political claims. The party thus mainly ran campaigns in opposition to the two leading Austrian parties

\footnotetext{
${ }^{13}$ Parties on the far-right increased their vote shares in recent decades all over Europe. The most prominent examples are the Front National (FN) in France, the Alternative for Germany (AfD) in Germany, the Freedom Party of Austria (FPÖ) in Austria, and the Dutch Wilders Group (formerly known as the Party for Freedom, PVV) in the Netherlands. In Scandinavian countries, parties of the far right, such as the Danish People's Party, the Sweden Democrats (SD) and the True Finns, saw increasing vote shares over the past decade. See Ignazi (2003) and Mudde (2013) for an overview.

${ }^{14}$ After we eliminate duplicates as well as FPÖ posters without a national or East Austrian reference, 636 individual posters remain. We label the slogans of these remaining posters according to their political statements or claims.
} 
- the Social Democratic Party (SPÖ) and the Conservative Party (ÖVP). ${ }^{15}$ From the late 1970 s until the mid-1980s, more liberal forces took over the FPÖ leadership and even formed a coalition government with the left-wing SPÖ. In this period, approximately $80 \%$ of all the poster slogans stated economic or Austrian internal political claims. There was a drastic change in 1986, when Jörg Haider - who would be the icon of Europe's right wing over the next twenty years (Ignazi 2003) - was elected as the new party leader. Haider realigned the FPÖ towards the far right. This shift is visible in the slogans, too. Haider's propaganda mainly targeted (Austrian) families and the homeland and came with a slight increase of anti-foreigner campaigns. In 2005, the even more radical wing of the FPÖ took control, led by Heinz-Christian Strache. Jörg Haider left the party and founded a new right-wing party (Bündnis Zukunft Österreich, BZÖ). Under Strache's leadership, campaigning against Turks and Muslims became one of the main strategies of the FPÖ. Islamophobia, however, was never an issue before 2005 in the FPÖ. ${ }^{16}$ On the contrary, Jörg Haider sought to work closely with the Islamic world. In 2002, for example, Haider met Saddam Hussein in Baghdad and even published a book to resolve the hardening relationship between the Iraqi dictator and the Western world. As the BZÖ leader, Haider visited the Arab world several times, had a friendship with the family of the Libyan dictator Mohammed Gadhafi, and even sponsored an Islamic cultural center in the city of Villach. Under Strache, however, 14\% of all the slogans became directly anti-Turkish or antiMuslim. In addition, general anti-foreigner slogans are often accompanied by anti-Turkish slogans. $^{17}$

\footnotetext{
${ }^{15}$ Austria's political landscape has traditionally been divided into three political camps: the Social Democrats, the Catholic conservatives and a right-wing camp (Ignazi 2003). Prior to WWII, the right-wing camp in Austria adhered to a pan-German ideology. After WWII, the VdU (Verband der Unabhängigen - Association of Independents) and in particular the FPÖ after 1955 consisted of former pan-German political leaders and electorate (Knight 1992, Luther 2000, Ignazi 2003).

${ }^{16}$ Note that the first anti-Turkish slogan of the FPÖ occurred in 2004 in the European Union parliamentary election campaign. This slogan, however, did not influence the election outcomes of the pre-Strache era because the previous election was held in 2002.

${ }^{17}$ Examples are "Deutsch-Wagram instead of Ibrahim and Abraham" from the 2008 national election campaign and "Heimatliebe statt Marokkaner-Diebe" (Love your country instead of Moroccan thieves) in 2012.
} 


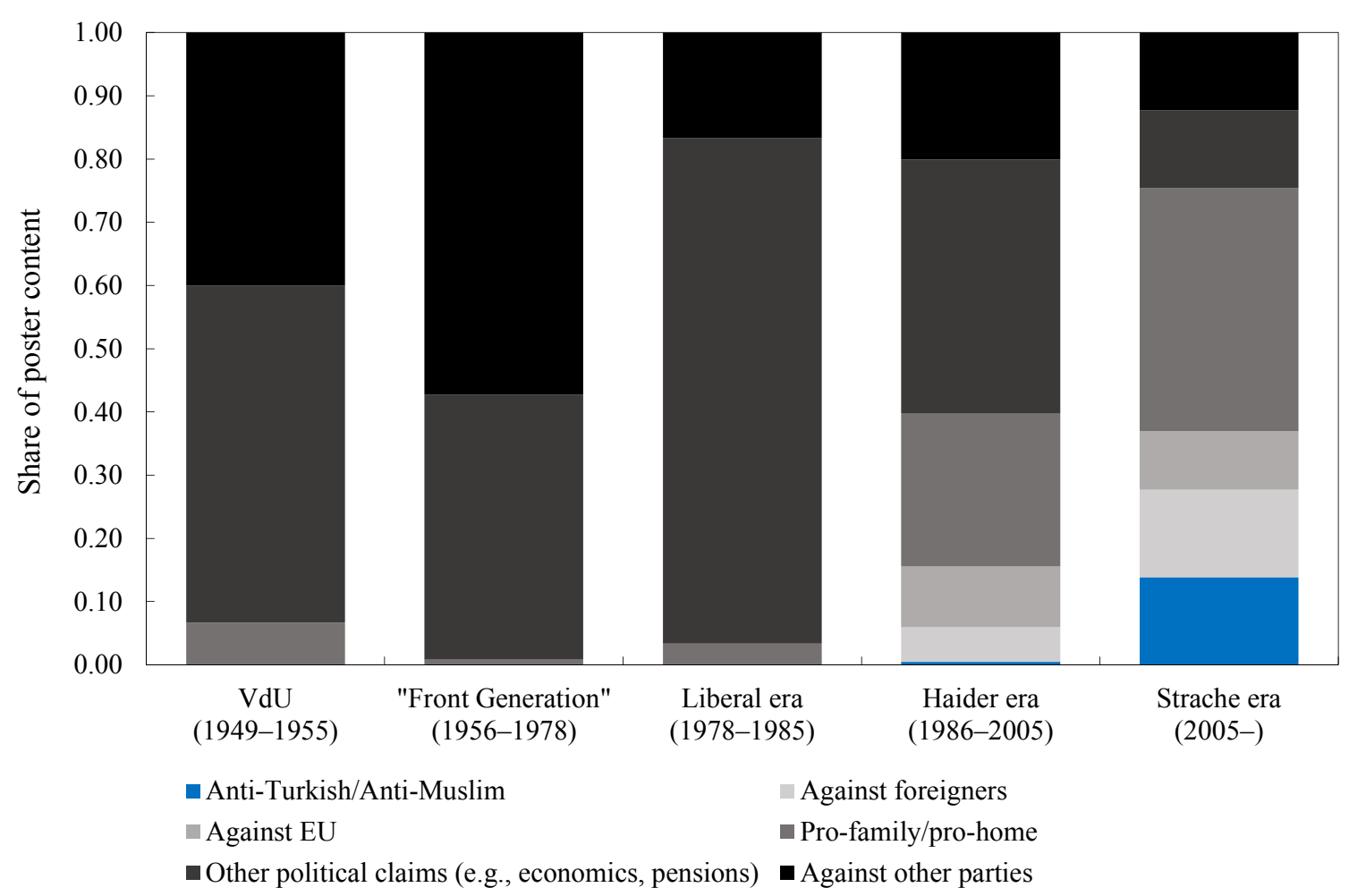

Notes: The figure shows a content analysis of 636 FPÖ political posters since 1949 according to the political (re)orientation of the FPÖ. These posters are based on either Austria-wide or East Austrian political campaigns. The posters are shared by the Austrian National Library. Other political claims are economic claims (e.g., taxes, wages), internal claims beyond family policies (e.g., social security, pensions), internal security (e.g., police, crime), and foreign policy (e.g., NATO, Schengen).

Anti-foreigner campaigns are often attributed to the rise of the populist right in Austria. Figure 5 shows the evolution of FPÖ shares of the votes cast in national elections in East Austria (the federal states of Lower Austria and Burgenland). The party played a minor role until the mid1980s. In the Haider era after 1986, electoral support surged for the first time, as it did after 2006. In 2002, the FPÖ dramatically lost electoral support after joining a coalition government with the conservative ÖVP. The FPÖ's anti-Turkish political campaign started in 2005 when the new party leader, Heinz-Christian Strache, issued the slogan "Pummerin instead of Muez$z i n$ " for the Vienna state parliament election. ${ }^{18}$ "Pummerin" is the Viennese name of the main

\footnotetext{
${ }^{18}$ Compared to other extreme right-wing parties in Europe, the FPÖ was rather late to start to campaign against Muslims in general and against Turks in particular. The British BNP started to campaign against Muslims already in 1999. Catalyzed by 9/11, the Front National in France raged against Arabs in the 2002 presidential elections,
} 
bell of St. Stephen's Cathedral, which was installed to commemorate the sieges of Vienna. The bell is cast partially from Turkish guns used in Siege II. Strache said that more than 320 years after Siege II, Vienna was under Turkish threat again. He stated that if the Turkish minority in Vienna continued to grow, the tower of St. Stephen's Cathedral will be converted into a minaret. In fact, the share of people with an Islamic denomination in Vienna was approximately $8 \% .{ }^{19}$ Furthermore, Strache used the slogan "Daham statt Islam" (home instead of Islam) in the national election campaign in 2006 and launched a petition against the veiling of women. Strache also used prejudice against Turkey in his campaigns after the European Union announced that it would open accession negotiations with Turkey in late 2005. However, Turkey had already been approved as a candidate country for the EU in 1999, six years before the FPÖ started its anti-Turkish campaigns. During the campaigns, Strache proclaimed the "Third Turkish Siege of Vienna", a term that had never before been used in any political campaign since WWII. ${ }^{20}$

From 2006 onwards, Strache cultivated anti-Turkish and anti-Muslim sentiments and referred even more drastically to the Turkish sieges of Vienna. For example, in 2010, the FPÖ published a comic called "Saga of Vienna". Party leader Strache was portrayed as the comic hero fighting against the Turks during Siege II. $^{21}$ The comic was illustrated with Turkish atrocities and showed an image of St. Stephen's Cathedral with two minarets that were crowned with Turkish crescents. The Turkish sieges were also an issue in the campaigns of local politicians. For instance, in a local party newspaper, a FPÖ local council member of the municipality of Sollenau (which was pillaged during Siege I and Siege II) accused the Turks of extreme cowardice except

and the Dutch Lijst Pim Fortuyn (LPF) campaigned against Islamic infiltration in the national parliamentary election in 2002. Anti-Islam campaigns increased further after the bomb attacks on the Madrid (2004) and London (2005) public transport system.

${ }^{19}$ Muslims are the second-largest religious community in Vienna after Catholics. In terms of foreign languages, only Serbian is spoken more often than Turkish by Viennese residents.

${ }^{20}$ The term "Third Turkish Siege of Vienna" first entered the public debate in 1983 during the 300th anniversary of Siege II (Dallinger 2013). In 2005, the Vienna Art Gallery held an exhibition called "KanakAttack: The Third Turkish Siege?" Among other events, the entire gallery building was covered with a Turkish flag.

${ }^{21}$ See https://www.youtube.com/watch?v=QSQ2qgKsrrU. 
when they are in a superior position, as they were during the sieges of Vienna (FPÖ Sollenau 2010). All these campaigns directly employ certain stereotypes of Turks and Muslims. In particular, the postulated Turkish and Muslim propensity to violence and the aim to dominate and oppress Austrian identity link the atrocities during the sieges of Vienna to current-day stereotypes. $^{22}$

FIGURE 5. FPÖ VOTE SHARES IN EAST AUSTRIA

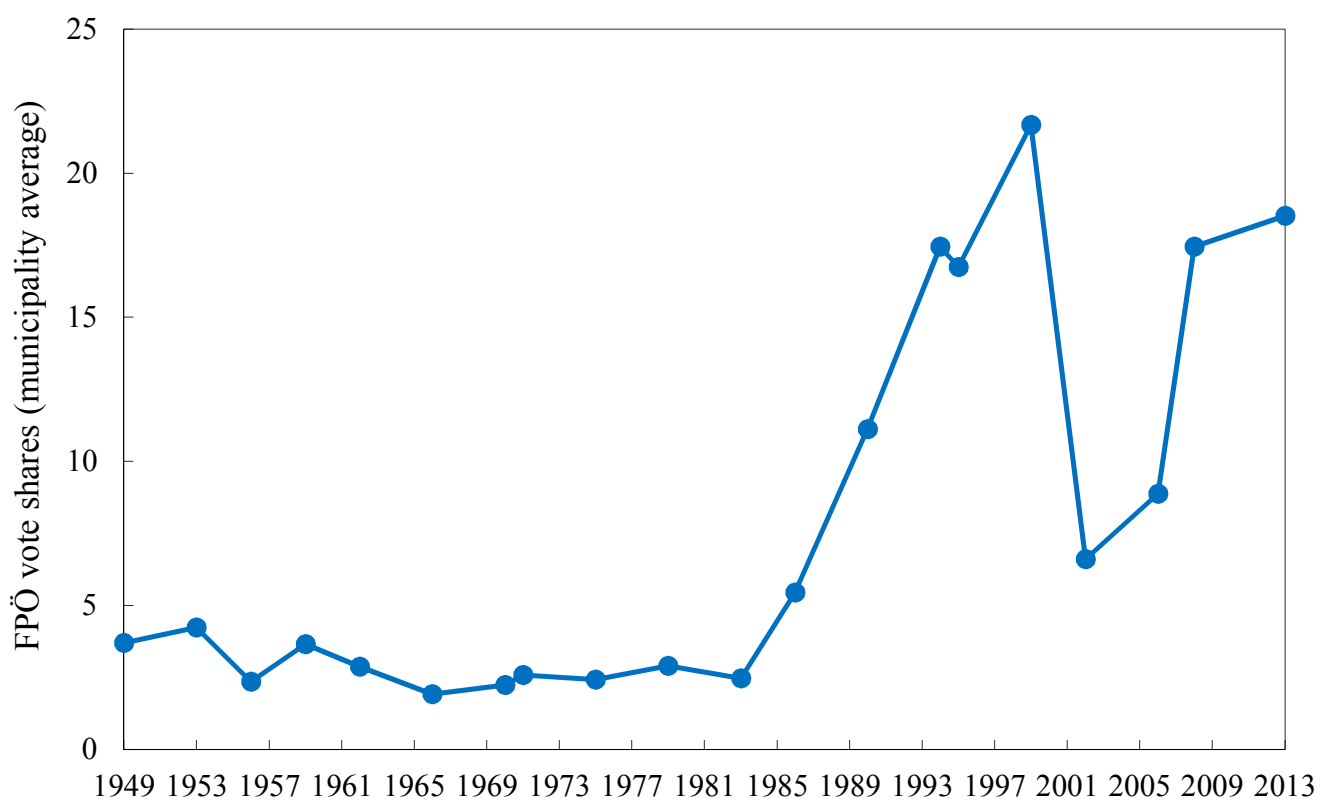

Notes: The figure shows the mean vote share of the FPÖ in 690 East Austrian municipalities in 20 national elections since 1949. The vote shares for 1949 and 1953 are for the VdU; those from 1956 to 2013 are for the FPÖ. National elections occurred in 1949, 1953, 1956, 1959, 1962, 1966, 1970, 1971, 1975, 1979, 1983, 1986, 1990, 1994, 1995, 1999, 2002, 2006, 2008, and 2013.

Anti-Turkish and anti-Muslim propaganda have continued until the present day. The large-scale migration from the Arab world towards Europe in 2015 has even accelerated these campaigns. In 2016, the FPÖ generously celebrated the 333-year anniversary of the end of Siege II in 1683. In conclusion, Austria's main right-wing party, the FPÖ, has conducted anti-foreigner campaigns for decades. Islamophobia or anti-Turkish propaganda, however, were not issues until

\footnotetext{
${ }^{22}$ Hilton and von Hippel (1996) define stereotypes as mental representations of real differences between groups. Often, stereotypes are formed about a certain group when the relative frequency of a certain attribute is much higher in that group than in the relevant reference group. See Bordalo et al. (2016) for a conceptual description.
} 
2005, when Heinz-Christian Strache became the leader of the FPÖ. After 2005, anti-Turkish and anti-Muslim campaigns increased rapidly and are a main element of the party's strategy today. In the following section, we outline our empirical strategy to investigate whether political campaigning that employs stereotypes is able to activate the long-gone past.

\section{Empirical strategy}

This section introduces our data and our identification strategy. In our baseline specification, we compare pre- and post-campaign right-wing voting in pillaged and non-pillaged municipalities within an OLS difference-in-differences model (Section 4.2). We also estimate a spatial fuzzy regression discontinuity $(\mathrm{RD})$ model that uses a regional subsample west of Vienna (West sample; see Section 4.3). In this West sample, Turkish troops and their auxiliary troops were stopped in the Battle of Bisamberg to further expand towards the west to the north of the Danube River (see Section 2.1; Gerhartl 1983, Stoye 2007). This battle induced arguably exogenous variation in municipalities' likelihood of being affected by Turkish pillages across the Danube River west of Vienna that allows us to address potential OLS difference-in-differences estimation biases through measurement errors and spatial spill-overs.

\subsection{Data}

We exploit spatial and time variation in 16th- and 17th-century Turkish violence across 690 East Austrian municipalities (the present-day federal states of Lower Austria and Burgenland). We digitize municipal-level hard-copy data for all 20 national elections since 1949 and transform data to a balanced panel of municipalities. ${ }^{23}$ Our dataset includes the vote shares of all the major political camps of Austria: the left-wing camp, consisting of the social-democratic SPÖ and the Green Party; the conservative ÖVP; and the right-wing camp that is led by the populist

\footnotetext{
${ }^{23}$ We use the most consolidated territorial status of the mid-1980s. After a wave of municipal mergers in the 1970s, some merged municipalities split again in the early 1990s. Today, East Austria consists of 744 municipalities.
} 
FPÖ. We match national census data to election data. ${ }^{24}$ Census data include demographics (share of females, share of foreigners, share of population younger than 20 and older than 65) and sectoral shares of agriculture and industry.

We self-compiled a dataset from various sources to identify whether a municipality has a record of Turkish atrocities or pillages. We used historical maps (Broucek, Hillbrand and Vesely 1983, Lacom 2009), local sources of information (e.g., municipal and church chronicles), and Wikipedia entries and screened related books (e.g., Gerhartl 1981, 1983, Gutkas 1973 and Hummelberger 1983). We coded a municipality as pillaged if any source indicated local Turkish attacks, pillages, murders, rapes, or kidnappings and zero otherwise. We also documented local violence records by foreign forces other than the Turks. The supplementary material offers more details of the data compilation.

Table 1 shows the summary statistics of our full sample. The upper panel shows how municipalities in East Austria were affected by foreign forces from the 15th century on. These forces were, in addition to the Turkish pillages, the Hungarians, the Swedes, Napoleon's troops, and the Hussites. We discuss the records of atrocities perpetrated by other foreign forces in Section 6.4. Average vote shares show that the conservative ÖVP and the left-wing SPÖ are the major political powers, even though their vote shares have eroded over the past three decades in favor of the far-right FPÖ. Table 1 also depicts socio-demographic variables and time-invariant geographic covariates. Our dataset also includes information on the location of historical infrastructure (monasteries and fortresses) and on pre-WWII national election outcomes in 1930.

\footnotetext{
${ }^{24} \mathrm{We}$ use the census data that are closest to the election data. Census data are available in ten-year intervals. Census data for 1951 and 1961 are based on Ergebnisse der Volkszählung vom 1. Juni 1951 nach Gemeinden, Heft 11 and Ergebnisse der Volkszählung vom 21. März 1961 nach Gemeinden, Heft 2 \& 7, respectively. Census data for 1971 until 2011 were retrieved from the Austrian Statistical Office (Statistik Austria). Due to a lack of more recent data, religious denominations are available only before 2001.
} 


\begin{tabular}{|c|c|c|c|c|c|}
\hline & Obs. & Mean & Std. Dev. & Min. & Max. \\
\hline & (1) & (2) & (3) & (4) & (5) \\
\hline \multicolumn{6}{|l|}{ Foreign forces in East Austria } \\
\hline Turkish pillages (Siege I or II) & 690 & 0.49 & 0.50 & 0 & 1 \\
\hline Turkish pillages (Siege I) & 690 & 0.32 & 0.47 & 0 & 1 \\
\hline Turkish pillages (Siege II) & 690 & 0.42 & 0.49 & 0 & 1 \\
\hline Hungarians ( 15 th century) & 690 & 0.23 & 0.42 & 0 & 1 \\
\hline Swedes $(1645 / 1646)$ & 690 & 0.13 & 0.34 & 0 & 1 \\
\hline Napoleonic troops (1805-1809) & 690 & 0.19 & 0.39 & 0 & 1 \\
\hline Hussites (1420-1434) & 690 & 0.10 & 0.30 & 0 & 1 \\
\hline \multicolumn{6}{|l|}{ Vote shares } \\
\hline FPÖ (Right-wing populist) & 13,800 & 7.76 & 7.18 & 0 & 35.80 \\
\hline$\ddot{O} V P$ (Conservative) & 13,800 & 48.72 & 17.73 & 5.80 & 97.62 \\
\hline SPÖ/Green Party (Left-wing) & 13,800 & 40.44 & 14.93 & 0 & 88.59 \\
\hline \multicolumn{6}{|l|}{ Socio-demographics } \\
\hline Electorate $(\log )$ & 13,800 & 7.15 & 0.73 & 4.06 & 10.63 \\
\hline Population share female & 13,800 & 51.60 & 1.67 & 41.43 & 61.93 \\
\hline Population share foreigners & 13,800 & 2.79 & 3.15 & 0 & 35.84 \\
\hline Population share $<20$ years & 13,800 & 27.13 & 5.68 & 11.27 & 47.84 \\
\hline Population share $>65$ years & 13,800 & 14.97 & 3.63 & 0 & 32.51 \\
\hline Share agriculture & 13,800 & 17.63 & 17.14 & 0.12 & 84.91 \\
\hline Share industry & 13,800 & 28.50 & 11.97 & 3.89 & 74.77 \\
\hline \multicolumn{6}{|l|}{ Geography } \\
\hline Burgenland (yes $=1$ ) & 690 & 0.20 & 0.40 & 0 & 1 \\
\hline Distance to Vienna & 690 & 65.55 & 33.23 & 10.33 & 151.34 \\
\hline Distance to external border & 690 & 30.82 & 22.28 & 0.40 & 88.70 \\
\hline Distance to highway & 690 & 13.56 & 14.10 & 0.52 & 78.88 \\
\hline South of Danube (yes $=1)$ & 690 & 0.65 & 0.48 & 0 & 1 \\
\hline
\end{tabular}

Notes: The table shows the summary statistics for 690 municipalities in East Austria. Data cover 20 national elections from 1949 to 2013, socio-demographic variables based on census and register data at ten-year intervals from 1951 to 2011 matched to the election closest to the census, and time-invariant geographic controls. Distance to highway is the municipal distance to the nearest highway slip road in 2016.

\subsection{Difference-in-differences}

As our baseline specification, we test whether right-wing voting in once pillaged municipalities differs from that in municipalities without a record of Turkish atrocities after anti-Turkish campaigns were launched in 2005 .

We use a difference-in-differences setting to identify the interaction effect of anti-Turkish campaigning and municipalities' exposure to Turkish pillages in the 16th and 17th centuries on the 
vote shares for the populist right-wing FPÖ. We will refer to this interaction effect as the activation effect. We specify the following difference-in-differences model:

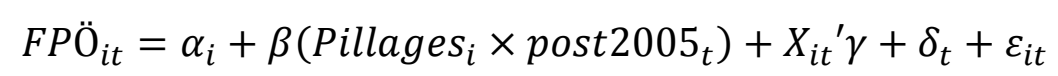

$$
\text { with } i=1, \ldots, 690 ; t=1, \ldots, 20
$$

where $F P \ddot{O}_{i t}$ is the dependent variable and describes the vote share for the right-wing party

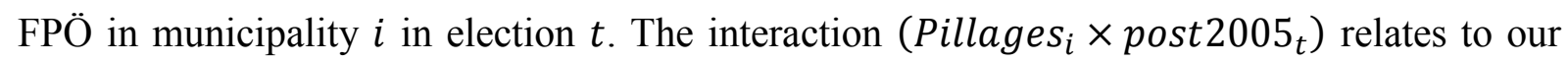
coefficient of interest, $\beta$. Pillage $e_{i}$ is a municipality-specific dummy that equals one if a municipality was once pillaged by the Turks and zero otherwise. The time-specific dummy variable post $2005_{t}$ equals one after 2005, when the right-wing FPÖ started anti-Turkish and antiMuslim campaigning (before 2005: zero). $\beta$ measures the activation effect. It measures to what extent the FPÖ vote share differs across pillaged and non-pillaged municipalities after antiTurkish and anti-Muslim campaigning began. The estimation equation includes municipalfixed effects, $\alpha_{i}$, to control for time-invariant local characteristics and election-fixed effects, $\delta_{t}$, to capture the political trend and temporal idiosyncrasies. The vector $X$ includes several control variables at the municipal level. We use the logarithm of the number of electorate as a proxy for municipal size. We also include socio-demographic variables (share of females, share of foreigners, age cohorts) and the sectoral shares of agriculture and industry. ${ }^{25} \mathrm{We}$ estimate the difference-in-differences model using Ordinary Least Squares (OLS) with standard errors clustered at the municipal level. We also experiment with standard errors robust to spatial correlation, as proposed by Conley $(1999,2008)$, but the inferences do not change.

Several estimation assumptions apply to our model. First, the key identifying assumption of the difference-in-differences approach is that municipalities in East Austria follow a common trend

\footnotetext{
${ }^{25}$ We match national elections to the nearest census or register data.
} 
in vote shares for the FPÖ that would have continued in the absence of anti-Turkish campaigning. Figure 6 shows that the assumption of common trends in the FPÖ vote shares in the pillaged and non-pillaged municipalities seems to be met in the period before 2005 . We plot the crosssectional mean difference in the FPÖ vote shares between the pillaged and non-pillaged municipalities for all the national elections after WWII (upper graphic). ${ }^{26}$ The mean difference in the FPÖ vote shares does not turn out to be significantly different from zero in the entire pre-2005 period. Therefore, we conclude that the pre-campaigning trends did not differ across pillaged and non-pillaged municipalities. After 2005, however, the FPÖ vote share increased in pillaged municipalities compared to the non-pillaged ones. The differences are statistically significant at the $1 \%$ level from the 2008 election onwards. Thus, after approximately six decades of equal vote shares, pillaged municipalities seemed to react to anti-Turkish campaigning. The effects are even more pronounced for a subsample of 301 municipalities west of Vienna (West sample; see lower graphic of Figure 6). We will discuss this subsample in more detail later.

\footnotetext{
${ }^{26}$ As indicated by Figure 1, pillaged municipalities are regionally clustered - especially south of the Danube River and around Vienna. The same holds for the FPÖ vote shares. We reduce unobservable heterogeneity by including district fixed effects. Districts are the upper-local administrative level; East Austria is divided into 28 administrative districts that consist of approximately 24 municipalities on average. We add the six district-free cities of Eisenstadt, Rust, St. Pölten, Krems an der Donau, Waidhofen an der Ybbs and Wiener Neustadt to their respective surrounding districts.
} 
Full sample

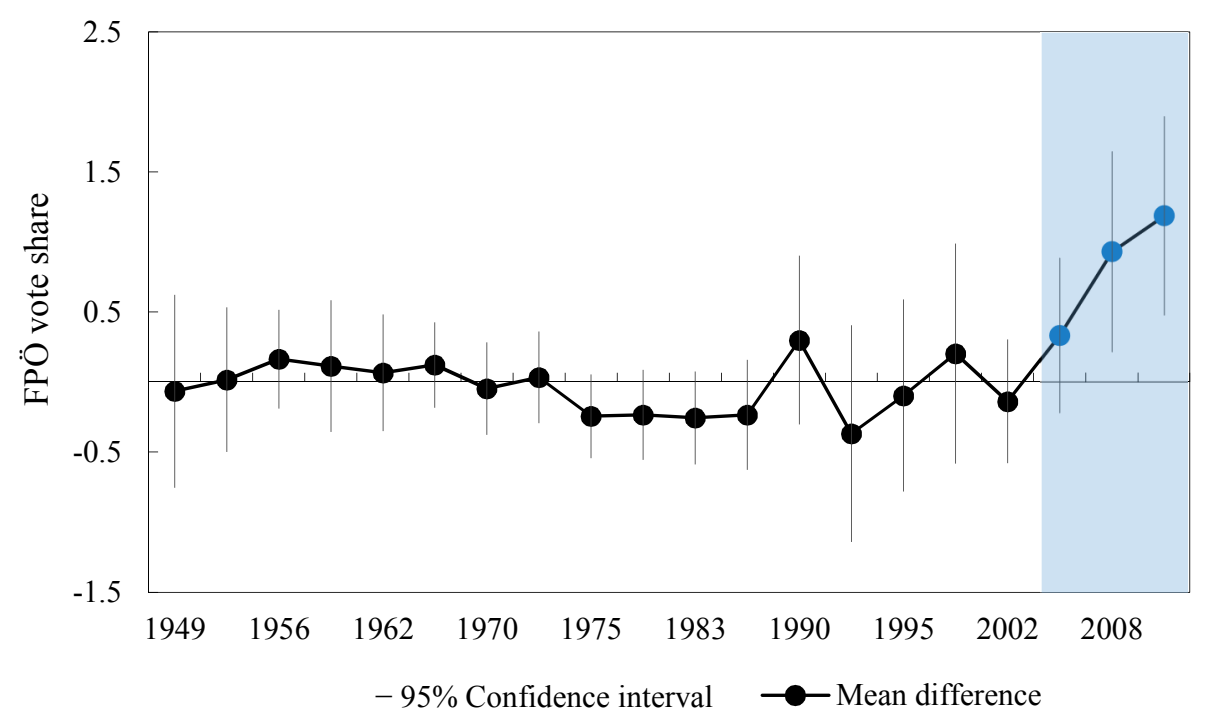

West sample

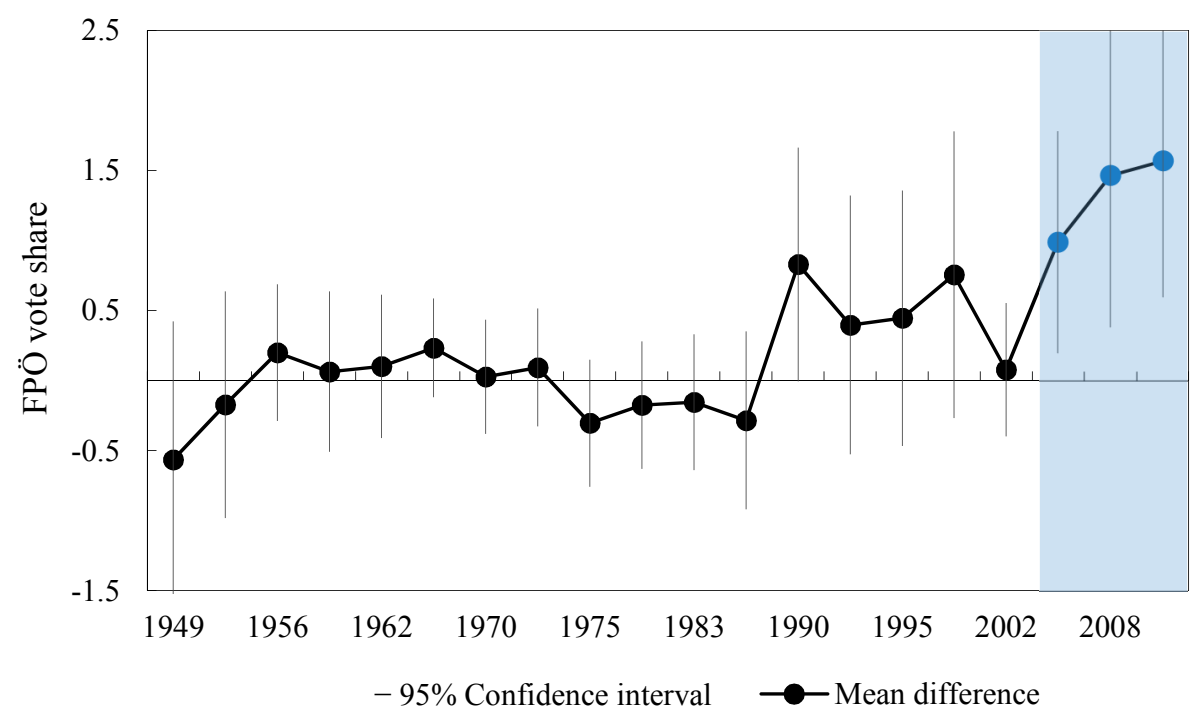

Notes: The figure shows the mean differences in FPÖ vote shares among pillaged and non-pillaged municipalities for the full sample $(n=690)$ and for a sample restricted to municipalities west of Bisamberg (West sample, $n=$ 301). Blue-shaded areas indicate the period after the anti-Turkish/anti-Muslim campaign began in 2005. The locations of the municipalities for the respective subsamples are shown in Figure 9. Means are conditional on district fixed effects. Vertical lines represent the 95\% confidence interval (robust standard errors).

Second, we investigate whether the pillages were orthogonal to observable characteristics prior to the Turkish invasions. Verbal evidence reports that the plundering Turkish forces dashed unsystematically around the country (see, e.g., Gerhartl 1981, Stoye 2007). Thus, we do not expect to find any systematic pillaging pattern. However, we conduct some formal tests. We 
geocode the historical infrastructure of the 15 th and early 16th centuries. These are 21 monasteries and 99 operating fortresses. ${ }^{27}$ Table 2, columns (1) and (2), shows the average distance of pillaged and non-pillaged municipalities from the nearest monastery and fortress, respectively, and whether a municipality hosts one of these infrastructures. In column (3), we test whether these differences between the pillaged and non-pillaged municipalities turn out to be significant. The Turkish attacks seem to be somewhat exogenous to 15 th- and 16th-century infrastructure. Being the sole exception, pillaged municipalities are somehow closer to a monastery by around 2 kilometers. ${ }^{28}$ In contrast, we expect that the probability of pillages may decrease in the distance to Vienna. First, Vienna was the main target of the Turkish troops, which resulted in higher exposure to atrocities and pillages for regions nearby. Second, the Turkish auxiliary troops were basically stopped by the Danube River west of Vienna. Crossing the Danube River was a difficult and dangerous endeavor in the 16th and 17th centuries. There were only a few bridges. The lower panel of Table 2 confirms this expectation: the pillaged municipalities are located closer to Vienna, and pillages were fairly rare north of the Danube River, especially west of Vienna (see also Figure 1). We will exploit these patterns within a fuzzy RD setting (see Section 4.2).

\footnotetext{
${ }^{27}$ The sources are Clam Martinic (1991) for operating fortresses in the 16th century and the "Referat für die Kulturgüter der Orden" (http://kulturgueter.kath-orden.at). Note that 18 of 21 monasteries that existed during the sieges of Vienna are still operating today.

${ }^{28}$ We perform a robustness check in Section 6 in which we control for the potential influence of historical infrastructure on present-day voting behavior.
} 
TABLE 2. DETERMINANTS OF TURKISH PILLAGES

\begin{tabular}{|c|c|c|c|}
\hline & Turkish pillages & No pillages & Difference \\
\hline & $(1)$ & $(2)$ & (3) \\
\hline \multicolumn{4}{|l|}{ Historical infrastructure } \\
\hline Distance to monastery in 1500 & 12.41 & 14.69 & $2.29 * * *$ \\
\hline Distance to fortress in 1500 & 8.69 & 8.95 & 0.25 \\
\hline Own monastery in 1500 & 0.06 & 0.04 & -0.02 \\
\hline Own fortress in 1500 & 0.12 & 0.13 & 0.01 \\
\hline \multicolumn{4}{|l|}{ Geography } \\
\hline Distance to Vienna & 52.61 & 78.19 & $25.58 * * *$ \\
\hline South of Danube River (yes $=1$ ) & 0.88 & 0.42 & $-0.46 * * *$ \\
\hline Obs. & 341 & 349 & 690 \\
\hline
\end{tabular}

Notes: Columns (1) and (2) shows the mean distance to historical infrastructure and geographic details of pillaged and non-pillaged municipalities. Column (3) shows the mean difference tests between pillaged and non-pillaged municipalities. Significance levels (robust standard errors): ***0.01,**0.05,*0.10.

Third, socio-demographic covariates should not show any treatment effect. Table 3 shows the mean differences of the pillaged and non-pillaged municipalities before campaigning (2001, column 1) and after campaigning (2011, column 2) and the difference-in-differences (column 3). ${ }^{29}$ Pillaged municipalities exhibit significantly higher shares of foreigners and higher unemployment rates than non-pillaged municipalities. These cross-sectional differences, however, do not change between 2001 and 2011. Moreover, we observe no significant changes in the covariates over time. Neither the share of Turkish foreigners nor the share of other foreigners (foreigners from outside the EU-15 member states and Turkey) differs statistically significantly in the cross-section and over time. In addition, the share of residents with an Islamic denomination does not differ among pillaged and non-pillaged municipalities in 2001 (denomination data are not available for 2011). Moreover, there has been no additional Turkish immigration pressure in East Austria during the past 30 years. Figure 10 in the supplementary material shows the evolution of the total share of foreigners and Turkish foreigners in East Austria separately since 1951 . Turkish immigration started during the economic boom period in the

\footnotetext{
${ }^{29}$ As in Figure 6, we include district fixed effects.
} 
1960s but suddenly stopped in the 1990s. Activation thus cannot be attributed to an increasing Turkish immigration pattern around 2005.

TABLE 3. DIFFERENCES IN COVARIATES BEFORE AND AFTER THE START OF CAMPAIGNING

\begin{tabular}{|c|c|c|c|}
\hline & \multicolumn{3}{|c|}{ Difference pillages vs. no pillages } \\
\hline & 2001 & 2011 & $\begin{array}{l}\text { Difference-in-difference } \\
\text { 2001-2011 }\end{array}$ \\
\hline & $(1)$ & $(2)$ & (3) \\
\hline \multicolumn{4}{|l|}{ Socio-demographics } \\
\hline Electorate $(\log )$ & $0.267 * * *$ & $0.279 * * *$ & 0.012 \\
\hline Population share female & $0.230^{*}$ & 0.194 & -0.036 \\
\hline Population share foreigners & 0.519 & 0.452 & -0.067 \\
\hline Population share EU-15 foreigners & $0.093 * * *$ & $0.135^{* *}$ & 0.042 \\
\hline Population share Turkish foreigners & 0.124 & 0.013 & -0.110 \\
\hline Population share other foreigners & 0.303 & 0.303 & 0.000 \\
\hline Population share $<20$ years & 0.107 & $0.331 *$ & 0.225 \\
\hline Population share $>65$ years & -0.264 & $-0.522 *$ & -0.258 \\
\hline Share agriculture & $-1.067 * *$ & $-0.720 * * *$ & 0.347 \\
\hline Share industry & 0.377 & 0.121 & -0.257 \\
\hline Population share unemployed & $0.135 * *$ & $0.149 * *$ & 0.014 \\
\hline Population share Catholics & $-2.329 * *$ & $\mathrm{n} / \mathrm{a}$ & - \\
\hline Population share Protestants & 0.942 & $\mathrm{n} / \mathrm{a}$ & - \\
\hline Population share Muslims & 0.263 & $\mathrm{n} / \mathrm{a}$ & - \\
\hline \multicolumn{4}{|l|}{ Geography } \\
\hline Distance to Vienna & $-4.521 * * *$ & $-4.521 * * *$ & - \\
\hline Distance to external border & 1.041 & 1.041 & - \\
\hline Distance to highway & -1.062 & -1.062 & - \\
\hline
\end{tabular}

Notes: Columns (1) and (2) show the mean differences in socio-demographic covariates and time-invariant geographic controls between pillaged and non-pillaged municipalities for the last census prior to 2001 and the first census after the start of the anti-Turkish campaigning (2011). Mean differences are conditional on district fixed effects. Column (3) depicts the respective difference-in-differences estimates. Significance levels (robust standard errors): ***0.01,**0.05,*0.10.

In conclusion, we show that trends in the FPÖ vote shares do not differ among pillaged and non-pillaged municipalities before the anti-Turkish campaigning. We also document how timeinvariant patterns such as the distance from Vienna and the geographic features determined Turkish movements, whereas the historical infrastructure basically does not predict pillages. Finally, no activation effects show up in the covariates. Thus, we propose that the main difference-in-differences assumptions seem to be met. 


\subsection{Spatial fuzzy RD}

We investigate data at the level of municipalities that are comparably small. Arguably, parts of the collective memory are region-specific rather than municipality-specific. For centuries, people have moved from, say, a pillaged municipality to a neighboring non-pillaged municipality and vice versa, e.g., because of marriages. There have also been rich interactions between municipalities due to commuting or local festivals. Thus, we cannot rule out the possibility that effects spill over from treated to untreated municipalities, which would challenge our baseline estimations. In addition, our data from municipal records of Turkish atrocities may face two potential measurement errors. First, the absence of a direct Turkish atrocities record does not necessarily mean that there was no violence. Information might have been lost due to pillages and slaughters; even entire localities disappeared, such as the village of Lebarn in the course of Siege I. Second, our online sources may suffer from endogeneity of FPÖ vote shares and (online) records of Turkish atrocities. These measurement errors may bias difference-in-differences in both directions: Coding treated municipalities as untreated would yield an underestimated campaigning effect in our difference-in-differences model, and endogeneity of FPÖ vote shares and online sources would result in overestimations.

In the context of our study, we take advantage of the role of the Danube River during the sieges of Vienna. West of Vienna, the Danube River constitutes an arguably fuzzy threshold for the probability of Turkish pillages. Regions south of the Danube River were heavily exposed to Turkish pillages, whereas adjacent regions north of the Danube River experienced hardly any Turkish atrocities. These differences in exposure to Turkish atrocities along the Danube River were caused mainly by the Battle of Bisamberg (see Figure 2), in which the Turkish army, accompanied by auxiliary troops, was stopped in its further westward expansion north of the Danube River (Gerhartl 1983; Stoye 2007). Only some minor troops crossed the Danube River towards the north during Siege I and Siege II and returned quickly to the south. We use the 
Danube River as an "assignment rule". The assignment rule predicts the actually realized assignments of a treatment and can be used in a 2SLS setup. In the first stage, we predict a municipality's likelihood of being pillaged based on its location with respect to the Danube River. We use the predicted values in the second stage. Technically, we instrument the interaction

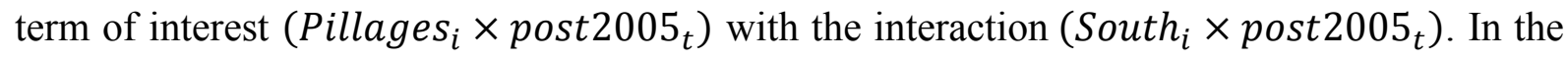
most basic specification, South ${ }_{i}$ is a dummy that equals one if municipality $i$ is located south of the Danube River. Later, we will extend South $_{i}$ to an RD polynomial using the distance to the Danube River as the running variable. We use a two-stage least squares (2SLS) procedure. Thus, we extend our difference-in-differences approach to a fuzzy spatial regression discontinuity (RD) design that allows us to address estimation biases due to local spill-overs and measurement errors. This strategy is rather new in a panel framework. So far, studies have applied a spatial fuzzy RD framework in the cross-section only, e.g., Eugster et al. (2011) and Basten and Betz (2013).

Fuzzy RD is equivalent to an instrumental variable approach (Angrist and Pischke 2010). Our instrument is the location of a municipality with respect to the Danube River, conditional on the campaigning period (after 2005). The instrument is highly relevant, as already indicated by the graphical inspection of Figure 1. As we will discuss below, first-stage F-statistics confirm this impression. We also conduct an RD plot, shown in Figure 7, that documents a sharp and significant spatial discontinuity in Turkish pillages across the Danube River in our West sample. The probability of pillages was approximately 0.6 for municipalities south of the Danube River (negative range in Figure 7); municipalities in the adjacent northern region (positive range) were only marginally exposed to Turkish pillages. 


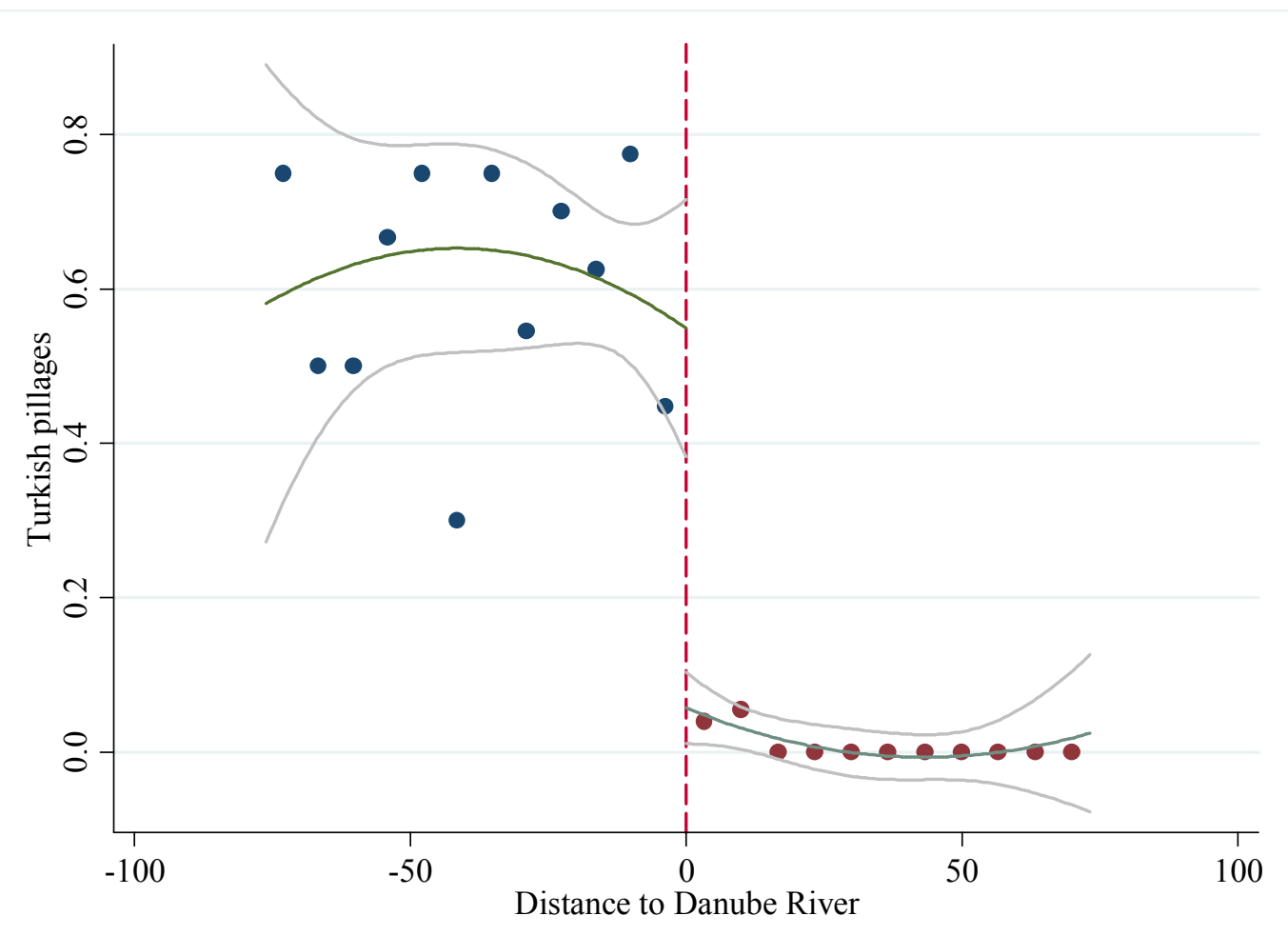

Notes: The figure shows an RDD plot of the Turkish pillages using the distance in kilometers to the Danube River as the running variable. The red dashed vertical line indicates the Danube River. The green lines show the local averages of municipalities' likelihood of being pillaged based on a quadratic polynomial fit. Negative values of the distance to the Danube River refer to municipalities south of the Danube River; positive values refer to municipalities north of the Danube River. The gray lines indicate 95\% confidence bands. For illustrative reasons, the number of bins equals 11 for each side of the threshold.

We also have good reasons to believe that our instrument is excludable. First, and most importantly, the main reason for the sharp spatial discontinuity in pillages is the arguably exogenous location of the Battle of Bisamberg. Turkish troops stopped expanding north of the Danube River west of Vienna because of their defeat. Second, even today, the Danube River west of Vienna is not a border between administrative districts in East Austria. Bridges and ferries allow crossings of the Danube River quite easily in the present day. Third, we find no evidence that the Danube River might have become an issue after 2005 but not in the years before. We do not observe changes in spatial discontinuities in covariates across the Danube River west of Vienna from the pre-campaigning to the campaigning period. Column (3) in Table 15 in the supple- 
mentary material shows that the FPÖ vote share is the sole exception, considering both its magnitude and its statistical significance. Furthermore, east of Vienna (longitude $>16.5^{\circ}$ ), the Danube River is not a geographic threshold for long-gone exposure to Turkish atrocities, and neither do the FPÖ vote shares show any differences from the pre-campaigning to the campaigning period (see the lower part of Table 15). Altogether, the location of a municipality with respect to the Danube River west of Vienna and conditional on time appears to be a relevant and excludable instrument that allows us to address local spill-overs and measurement errors.

\section{Results}

\subsection{Baseline}

We test mean differences of pillaged and non-pillaged municipalities in a panel framework, as described above. Table 4 shows our baseline difference-in-differences results for the full sample and the West sample, which we will explore in more detail in a spatial fuzzy RD framework. Columns (1) and (3) show the coefficient of the interaction term without any control variables except municipality and time fixed effects. In columns (2) and (4), we include the full set of control variables. 


\begin{tabular}{|c|c|c|c|c|}
\hline & \multicolumn{4}{|c|}{ FPÖ vote share } \\
\hline & \multicolumn{2}{|c|}{ Full sample } & \multicolumn{2}{|c|}{ West sample } \\
\hline & \multicolumn{2}{|c|}{ OLS } & \multicolumn{2}{|c|}{ OLS } \\
\hline & (1) & (2) & (3) & (4) \\
\hline \multirow[t]{2}{*}{ Turkish pillages $\times$ Post- 2005} & $1.684 * * *$ & $1.091 * * *$ & $2.121 * * *$ & $1.557 * * *$ \\
\hline & $(0.228)$ & $(0.207)$ & $(0.302)$ & $(0.292)$ \\
\hline \multirow[t]{2}{*}{ Electorate (log) } & & $1.557 * * *$ & & $1.865 * * *$ \\
\hline & & $(0.379)$ & & $(0.483)$ \\
\hline \multirow[t]{2}{*}{ Population share female } & & 0.020 & & 0.041 \\
\hline & & $(0.041)$ & & $(0.054)$ \\
\hline \multirow[t]{2}{*}{ Population share foreigners } & & $0.053 * *$ & & $0.165^{* * *}$ \\
\hline & & $(0.024)$ & & $(0.040)$ \\
\hline \multirow[t]{2}{*}{ Population share $<20$ years } & & 0.030 & & 0.030 \\
\hline & & $(0.021)$ & & $(0.028)$ \\
\hline \multirow[t]{2}{*}{ Population share $>65$ years } & & $-0.116^{* * *}$ & & -0.012 \\
\hline & & $(0.027)$ & & $(0.039)$ \\
\hline \multirow[t]{2}{*}{ Share agriculture } & & $-0.023 * *$ & & $-0.035 * *$ \\
\hline & & $(0.011)$ & & $(0.016)$ \\
\hline \multirow[t]{2}{*}{ Share industry } & & $-0.058 * * *$ & & $-0.047 * *$ \\
\hline & & $(0.012)$ & & $(0.019)$ \\
\hline \multirow[t]{2}{*}{ Constant } & $3.694 * * *$ & -5.310 & $4.376^{* * *}$ & $-9.025^{*}$ \\
\hline & $(0.121)$ & $(3.560)$ & $(0.161)$ & $(4.693)$ \\
\hline Obs. & 13,800 & 13,800 & 6,020 & 6,020 \\
\hline Municipalities & 690 & 690 & 301 & 301 \\
\hline Year fixed effects & Yes & Yes & Yes & Yes \\
\hline Municipality fixed effects & Yes & Yes & Yes & Yes \\
\hline$R$-squared (within) & 0.904 & 0.909 & 0.919 & 0.922 \\
\hline \multicolumn{5}{|l|}{ Conley standard errors } \\
\hline \multirow[t]{2}{*}{ Turkish pillages $\times$ Post-2005 (cutoff $5 \mathrm{~km})$} & $1.684 * * *$ & $1.091 * * *$ & $2.121 * * *$ & $1.557 * * *$ \\
\hline & $(0.163)$ & $(0.150)$ & $(0.196)$ & $(0.194)$ \\
\hline \multirow[t]{2}{*}{ Turkish pillages $\times$ Post-2005 (cutoff $10 \mathrm{~km})$} & $1.684 * * *$ & $1.091 * * *$ & $2.121 * * *$ & $1.557 * * *$ \\
\hline & $(0.212)$ & $(0.191)$ & $(0.220)$ & $(0.224)$ \\
\hline \multirow[t]{2}{*}{ Turkish pillages $\times$ Post 2005 (cutoff $50 \mathrm{~km})$} & $1.684 * * *$ & $1.091 * * *$ & $2.121 * * *$ & $1.557 * * *$ \\
\hline & $(0.211)$ & $(0.213)$ & $(0.269)$ & $(0.270)$ \\
\hline
\end{tabular}

Notes: The dependent variable is the FPÖ vote share at the level of 690 East Austrian municipalities. The full sample consists of all sample municipalities in East Austria $(n=690)$, and the "West sample" consists of municipalities west of Vienna $(n=301)$. Significance levels (standard errors clustered at municipality level; the lower panel reports Conley standard errors for different spatial cutoffs): $* * * 0.01, * * 0.05, * 0.10$.

The results indicate a positive and highly statistically significant activation effect of anti-Turkish campaigning and 16th- and 17th-century Turkish pillages on FPÖ vote shares. In the full sample, FPÖ vote shares in pillaged municipalities increased by 1.1 to 1.7 percentage points compared to the vote shares in non-pillaged municipalities. This indicates that the collective memory in once pillaged municipalities contributes an "extra boost" to FPÖ vote shares through 
FPÖ campaigning. This result is substantial given the average FPÖ vote shares of approximately 16 percent in once pillaged municipalities after 2005 . This translates into a lower-bound persuasion rate of approximately 7 percent (1.1/16) and an upper-bound persuasion rate of 11 percent (1.7/14). In other words, at least 1 in 14 FPÖ voters in a once pillaged municipality cast a vote due to the different recognition of the collective memory stimulated by campaigning. The effect is somewhat larger in the more homogeneous West sample (1.6 to 2.1 percentage points) and translates to a persuasion rate of 10 to 13 percentage points. ${ }^{30}$ Corroborating the findings of Halla, Wagner and Zweimüller (2016), the share of foreigners is positively correlated with FPÖ vote shares. Larger agriculture and industry sectors, however, are associated with decreases in FPÖ vote shares. We find no significant effects of further control variables. Inferences do not change when we interact year fixed with the distance to Vienna to control for a potential time-variant trigger of the closeness to Vienna (see Table 16 in the supplementary material).

\subsection{Spatial fuzzy RDD}

We already outlined concerns regarding potential biases in measuring pillages and in the selection into treatment. We thus estimate a fuzzy RD model using a 2 SLS procedure. In this exercise, we refer to the subsample of municipalities west of Vienna (West sample). In this sample, the Danube River constitutes a quasi-exogenous fuzzy threshold in pillages. We thus instrument the activation effect with an interaction effect of being south of the Danube River and the campaigning period.

Table 5 reports the spatial fuzzy RD results. There, the interaction term can be interpreted as differences in FPÖ vote shares between municipalities located in regions that were heavily ex-

\footnotetext{
${ }^{30}$ The persuasion rate is computed by dividing the activation effect $(1.6 \%$ or $2.1 \%)$ by the average FPÖ vote shares of $15.8 \%$ in the once pillaged municipalities west of $16^{\circ}$ longitude.
} 
posed to Turkish atrocities during the sieges (south of the Danube River) and adjacent municipalities located in regions that were only marginally affected (north of the Danube River). We estimate different fuzzy RD specifications by replacing the geography dummy (the dummy takes a value of one if a municipality is located south of the Danube River) with a polynomial measuring of the geographic distance to the Danube River. Higher polynomial orders allocate more weight to observations that are near the Danube River.

We first turn to the first-stage results. The lower panel of Table 5 shows that our instrument works well, independent of the chosen polynomial order. The location of a municipality with respect to the Danube River predicts Turkish pillages in the 16th and 17th century quite well.

The upper panel of Table 5 depicts our second-stage results. The results are highly statistically significant and substantially larger than the OLS difference-in-differences point estimates. During the FPÖ anti-Turkish and anti-Muslim campaigns, FPÖ vote shares in municipalities that were heavily exposed to Turkish pillages (south of the Danube River) increased by approximately 3 percentage points compared to marginally affected municipalities. This result is larger than the difference-in-differences activation effects of approximately 1.6 to 2.1 percent (see Table 4, West sample). Addressing potential measurement errors and spill-overs thus increases the activation effect. The activation effect in the fuzzy RD estimates translates to a persuasion rate of up to $20 \% .^{31}$ Thus, nearly 1 in 5 FPÖ voters from a municipality in the heavily affected region voted for the FPÖ because of the collective memory that was activated by campaigning. The activation effects decrease slightly in magnitude when we use the distance to the Danube River in a higher polynomial specification of the 2SLS first stage. Columns (2) to (6) apply a linear interacted polynomial fit and use different regional subsamples with respect to the eastwest dimension (column 3) and the distance to the Danube River (columns 4 to 6). We also

\footnotetext{
${ }^{31}$ Persuasion is computed by dividing the activation effect (3.05\%) by the average FPÖ vote shares (15.3\%) after 2005 in municipalities south of the Danube River and west of $16^{\circ}$ longitude.
} 
estimate quadratic polynomial fuzzy RD specifications for the first stage in column (7). Compared to the baseline specification in column (1), the first-stage effects become somewhat smaller, but the overall results in the second stage do not change much. Thus, all the results hold in a 2SLS framework using the Danube River as an arguably exogenous source of variation.

TABLE 5. SPATIAL FUZZY RD RESULTS

\begin{tabular}{|c|c|c|c|c|c|c|c|}
\hline & \multicolumn{7}{|c|}{ FPÖ vote share } \\
\hline & \multicolumn{7}{|c|}{ West sample } \\
\hline & \multicolumn{7}{|c|}{ 2SLS (Fuzzy RD) } \\
\hline & Dummy & \multicolumn{5}{|c|}{ Linear } & Quadratic \\
\hline & Full & Full & East of $15^{\circ}$ & $\begin{array}{c}\text { Max. } 50 \\
\text { km to } \\
\text { Danube }\end{array}$ & $\begin{array}{c}\text { Max. } 40 \\
\text { km to } \\
\text { Danube }\end{array}$ & $\begin{array}{c}\text { Max. } 30 \\
\text { km to } \\
\text { Danube }\end{array}$ & Full \\
\hline & $(1)$ & $(2)$ & (3) & $(4)$ & $(5)$ & $(6)$ & (7) \\
\hline Turkish pillages $\times$ Post-2005 & $\begin{array}{c}3.053 * * * \\
(0.510)\end{array}$ & $\begin{array}{c}3.047 * * * \\
(0.512)\end{array}$ & $\begin{array}{c}3.141 * * * \\
(0.542)\end{array}$ & $\begin{array}{c}2.531 * * * \\
(0.554)\end{array}$ & $\begin{array}{c}2.620 * * * \\
(0.531)\end{array}$ & $\begin{array}{c}2.841 * * * \\
(0.547)\end{array}$ & $\begin{array}{c}2.803 * * * \\
(0.502)\end{array}$ \\
\hline Obs. & 6,020 & 6,020 & 4,960 & 5,220 & 4,520 & 3,880 & 6,020 \\
\hline Municipalities & 301 & 301 & 248 & 261 & 226 & 194 & 301 \\
\hline Socio-demographic controls & Yes & Yes & Yes & Yes & Yes & Yes & Yes \\
\hline Year fixed effects & Yes & Yes & Yes & Yes & Yes & Yes & Yes \\
\hline Municipality fixed effects & Yes & Yes & Yes & Yes & Yes & Yes & Yes \\
\hline \multicolumn{8}{|l|}{ First stage } \\
\hline South of Danube $\times$ Post -2005 & $\begin{array}{c}0.578 * * * \\
(0.040)\end{array}$ & $\begin{array}{c}0.540 * * * \\
(0.065)\end{array}$ & $\begin{array}{c}0.566 * * * \\
(0.074)\end{array}$ & $\begin{array}{c}0.526 * * * \\
(0.076)\end{array}$ & $\begin{array}{c}0.487 * * * \\
(0.083)\end{array}$ & $\begin{array}{c}0.430 * * * \\
(0.093)\end{array}$ & $\begin{array}{c}0.479 * * * \\
(0.094)\end{array}$ \\
\hline F statistic of excluded instrument & 204.86 & 72.90 & 63.53 & 59.89 & 57.53 & 57.34 & 43.94 \\
\hline KP rk LM statistic (p-value) & 0.000 & 0.000 & 0.000 & 0.000 & 0.000 & 0.000 & 0.000 \\
\hline Hansen J statistic (p-value) & 0.000 & 0.000 & 0.000 & 0.000 & 0.000 & 0.000 & 0.000 \\
\hline
\end{tabular}

Notes: The dependent variable is the FPÖ vote share at the level of 301 municipalities of the West sample $(n=$ 301). In column (1), we instrument $\left(\right.$ Pillages $_{i} \times$ Campaining $\left._{t}\right)$ by $\left(\right.$ South $_{i} \times$ Campaining $\left._{t}\right)$. In columns (2) to (7), we extend South $h_{i}$ to an RD polynomial using the distance to the Danube River. Column (2) applies a linear specification with the entire West sample; columns (3) to (6) restrict the West sample according to latitude (column (3)), and according to the distance to the Danube River (columns (4) to (6)). Column (7) applies a quadratic specification. Significance levels (standard errors clustered at municipality level): ***0.01, ** 0.05, * 0.10 .

\section{Robustness}

We undertake several analyses that may challenge our main explanatory variable (Turkish pillages, Sections 6.1 to 6.4 ) and our dependent variable (Sections 6.5 and 6.6). In particular, we investigate pseudo-treatment periods and different exposures to Turkish pillages (e.g., Siege I and Siege II separately), test the effect of historical infrastructure, and analyze pillages by other 
foreign forces. We also investigate the activation effect on other Austrian right-wing parties that do not campaign against Turkish or Muslim foreigners and the pre-WWII period of radicalization. As the main result, we show that both anti-Turkish campaigning and former Turkish pillages are each a necessary condition to obtain a significant activation effect.

\subsection{Timing of campaigning}

We perform several checks to confirm the robustness of our pillaging variable. In Table 6, we interact the pre-campaigning periods with the pillaging variable. Column (1) reproduces our baseline results, as shown in Table 4. We now roll over the treatment period to the elections prior to the start of the anti-Turkish and anti-Muslim campaigning in 2005; these are the elections of 1995, 1999 and 2002 (column 2). We then address potential activation due to the celebration of the 300th anniversary of Siege II in 1983 by rolling over the treatment period to the elections in 1983, 1986, 1990, and 1994 (column 3). As expected, neither column (2) nor column (3) shows any pseudo-campaigning effects in pillaged municipalities. Column (4) provides the combined estimation when we include all the pseudo-treatment periods and our original treatment variable. In this case, we find some significant results of the post-1983 pseudo-treatment, which are, however, small in size compared to the post-2005 effect. Large-scale celebrations that were accompanied by increases in media coverage may explain these small post-1983 effects (see Dallinger 2013, Pfeifer 2013). Note, however, that we find no significant effect when we investigate the post-1983 period separately. Altogether, we can rule out that our results suffer from some spurious activation pattern with respect to the timing of the campaigns. In other words, anti-Turkish campaigning is a necessary condition for our activation effect. 


\begin{tabular}{|c|c|c|c|c|}
\hline & \multicolumn{4}{|c|}{ FPÖ vote share } \\
\hline & \multicolumn{4}{|c|}{ Full sample } \\
\hline & \multicolumn{4}{|c|}{ OLS } \\
\hline & (1) & (2) & (3) & (4) \\
\hline \multirow[t]{2}{*}{ Turkish pillages $\times$ Post-2005 (2005-2013) } & $1.091 * * *$ & & & $1.236^{* * *}$ \\
\hline & $(0.207)$ & & & $(0.256)$ \\
\hline \multirow[t]{2}{*}{ Turkish pillages $\times$ Pre-Campaigning (1995-2004) } & & -0.096 & & 0.262 \\
\hline & & $(0.147)$ & & $(0.210)$ \\
\hline \multirow[t]{2}{*}{ Turkish pillages $\times$ Post-1983 (1983-1994) } & & & -0.015 & $0.299 * *$ \\
\hline & & & $(0.099)$ & $(0.147)$ \\
\hline Obs. & 13,800 & 13,800 & 13,800 & 13,800 \\
\hline Municipalities & 690 & 690 & 690 & 690 \\
\hline Socio-demographic controls & Yes & Yes & Yes & Yes \\
\hline Year fixed effects & Yes & Yes & Yes & Yes \\
\hline Municipality fixed effects & Yes & Yes & Yes & Yes \\
\hline$R$-squared (within) & 0.909 & 0.908 & 0.908 & 0.909 \\
\hline
\end{tabular}

Notes: The dependent variable is the FPÖ vote share at the level of 690 East Austrian municipalities. Column (1) replicates the baseline results. Columns (2) and (3) use pseudo-campaign periods. Column (4) shows the combined estimation with three subsequent (pseudo-)campaign periods from 1983 onwards. Significance levels (standard errors clustered at municipality level): ***0.01,**0.05, *0.10.

\subsection{Definition of pillages}

We test whether our results might be driven by an imprecise measures of our pillaging variable. Our fuzzy RD results already indicated that our results are robust to measurement errors. However, we also test some modifications of the dummy variable that measures Turkish pillages. Table 7 shows the results. In column (2), we extend the definition of pillaged municipalities by including 11 non-pillaged municipalities that commemorate the Turkish attacks in general, e.g., in local memorials. The point estimate slightly increases. In columns (3) and (4), we compare municipalities with a record of Turkish atrocities for only one of the two sieges to municipalities with no record of Turkish atrocities. Thus, we exclude municipalities that were pillaged in the respective other siege or in both sieges. The coefficients indicate that the activation pattern is somewhat stronger when a municipality was pillaged in Siege II compared to Siege I. This is consistent with anecdotal evidence that the local public is often more aware of Siege II than of Siege I (e.g., Pfeifer 2013). Finally, in column (5), we exclude the pillaged municipalities with 
a single source of information regarding their exposure to Turkish atrocities (see the supplementary material). The results are very robust compared to the baseline results. We interpret these results as further evidence that our results do not suffer from a (downward) measurement bias.

TABLE 7. DEFINITION OF PILLAGES

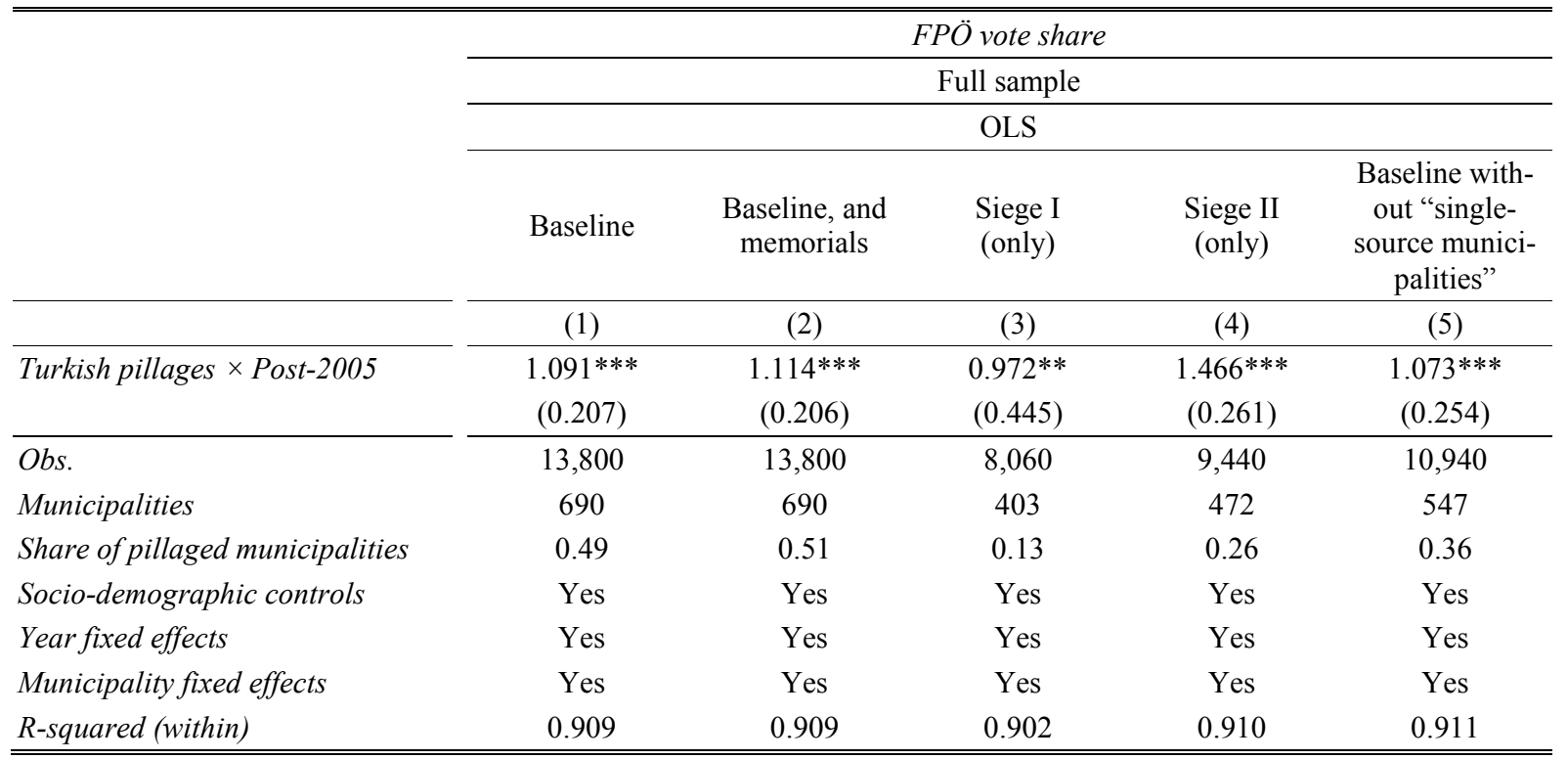

Notes: The dependent variable is the FPÖ vote share at the level of 690 East Austrian municipalities. Column (1) replicates the baseline results. In column (2), we add non-pillaged municipalities with a "visual memory" that commemorates the sieges in those municipalities. In column (3), we compare municipalities that were pillaged only in Siege I to municipalities that were never pillaged. In column (4), we compare municipalities that were pillaged only in Siege II to municipalities that were never pillaged. In column (5), we compare pillaged municipalities with exposure to Turkish atrocities documented by at least two different sources of information to nonpillaged municipalities (see the supplementary material). Significance levels (standard errors clustered at municipality level): $* * * 0.01, * * 0.05, * 0.10$.

\subsection{Historical determinants of Turkish pillages}

Unobservable municipal characteristics may have influenced both the probability of being pillaged during the sieges of Vienna and the current shift in FPÖ vote shares. In this case, our estimations would suffer from an omitted variable bias. To address this issue, we again refer to the data on historical infrastructure that were introduced in Section 4.2 and Table 2. Turkish troops might have avoided attacking villages that were near a fortress or monastery. ${ }^{32}$ At the

\footnotetext{
${ }^{32}$ However, as indicated in Table 2, only the distance to the next monastery differs among the pillage status factors.
} 
same time, a monastery may influence the present-day election decisions of residents nearby. Of the 21 monasteries that existed during the sieges, 18 are still operating today. The same might hold true for the 99 historical fortresses, most of which are still visible and accessible today. We interact the distance of a municipality to the nearest fortress or monastery with the campaigning variable and add this term to the baseline specification. Table 8 shows these results. Neither monasteries nor fortresses nearby explain the shift in the FPÖ vote shares after 2005. In addition, the original activation effect remains fairly unchanged.

TABLE 8. HISTORICAL DETERMINANTS OF TURKISH PILLAGES

\begin{tabular}{|c|c|c|c|c|}
\hline & \multicolumn{4}{|c|}{ Vote shares } \\
\hline & \multicolumn{4}{|c|}{ Full sample } \\
\hline & \multicolumn{4}{|c|}{ OLS } \\
\hline & Baseline & Monasteries & Fortresses & $\begin{array}{c}\text { Monasteries and } \\
\text { Fortresses }\end{array}$ \\
\hline & $(1)$ & (2) & (3) & (4) \\
\hline Turkish pillages $\times$ Post -2005 & $\begin{array}{c}1.091 * * * \\
(0.207)\end{array}$ & $\begin{array}{c}1.104 * * * \\
(0.207)\end{array}$ & $\begin{array}{c}1.091 * * * \\
(0.207)\end{array}$ & $\begin{array}{c}1.103 * * * \\
(0.207)\end{array}$ \\
\hline Distance monasteries $\times$ Post -2005 & & $\begin{array}{c}0.008 \\
(0.012)\end{array}$ & & $\begin{array}{c}0.008 \\
(0.012)\end{array}$ \\
\hline Distance fortresses $\times$ Post -2005 & & & $\begin{array}{c}0.008 \\
(0.016)\end{array}$ & $\begin{array}{c}0.007 \\
(0.016)\end{array}$ \\
\hline Obs. & 13,800 & 13,800 & 13,800 & 13,800 \\
\hline Municipalities & 690 & 690 & 690 & 690 \\
\hline Socio-demographic controls & Yes & Yes & Yes & Yes \\
\hline Year fixed effects & Yes & Yes & Yes & Yes \\
\hline Municipality fixed effects & Yes & Yes & Yes & Yes \\
\hline$R$-squared (within) & 0.909 & 0.909 & 0.909 & 0.909 \\
\hline
\end{tabular}

Notes: The dependent variable is the FPÖ vote share at the level of 690 East Austrian municipalities. Column (1) replicates the baseline results. In columns (2) and (3), we add interaction terms of municipalities' distance to the nearest historical infrastructure (monastery, fortress) with campaigning to the baseline specification. Column (4) shows the combined estimates. Significance levels (standard errors clustered at municipality level): $* * * 0.01, * *$ $0.05, * 0.10$.

\subsection{Pillages by other foreign forces}

East Austria experienced several hostile invasions in past times. Some municipalities were affected not only by Turkish atrocities but also by, e.g., Hungarian and Swedish troops. FPÖ campaigns solely and explicitly refer to the Turks. An activation pattern of the FPÖ campaigns 
by a general exposure to atrocities and pillages in past times might challenge a direct link between anti-Turkish campaigns and exposure to Turkish atrocities if the affected municipalities heavily overlap. We thus test whether local atrocity records of other foreign forces challenge our results. We collect municipal-level data for five other foreign forces that have entered East Austria since the 15th century. These are the Hussites from Bohemia (1420 to 1434; see Petrin 1982), the Hungarians under Corvinus (late 15th century; Rázsó 1973), ${ }^{33}$ Swedish troops during the Thirty Years War (1645/46; Broucek 1989), and Napoleonic troops (1805 to 1809; Egger 1964, Rauchensteiner 1994). Finally, all municipalities under investigation were occupied by the Red Army during WWII in 1945 (Erickson 1950). Figure 11 in the supplementary material gives a geographic impression of the municipalities affected by Turkish and by other foreign forces.

We re-perform the regressions shown in Table 4 but add interaction terms of atrocity records

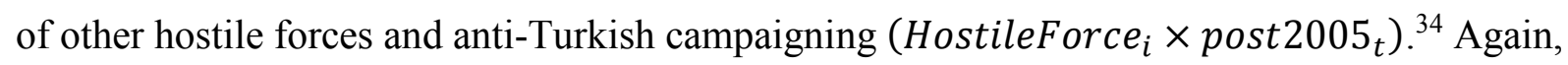
post $2005_{t}$ refers to the period of anti-Turkish campaigning by the FPÖ after 2005 . The results are shown in Table 9. We find no significant effect of a Hungarian, Swedish, or Napoleonic presence in East Austria. The effect of the Hussites is rather weak (10\% significance level) and has a negative sign. In none of the specifications, the effect of Turkish atrocities changes in significance and magnitude. We thus conclude that both anti-Turkish campaigning and a record of Turkish atrocities are necessary conditions for activation.

\footnotetext{
${ }^{33}$ Note that in some municipal chronicles, the Kuruc (a Christian minority of the Turkish auxiliary troops) are described as Hungarians. However, we label a municipality as treated by Hungarians as long as Hungarians are explicitly stated, independent of whether these were Hungarian troops in the $15^{\text {th }}$ century or the Kuruc labeled as Hungarians in the $17^{\text {th }}$ century.

${ }^{34}$ We do not investigate the occupation by the Red Army because all the municipalities under investigation would be treated equally.
} 


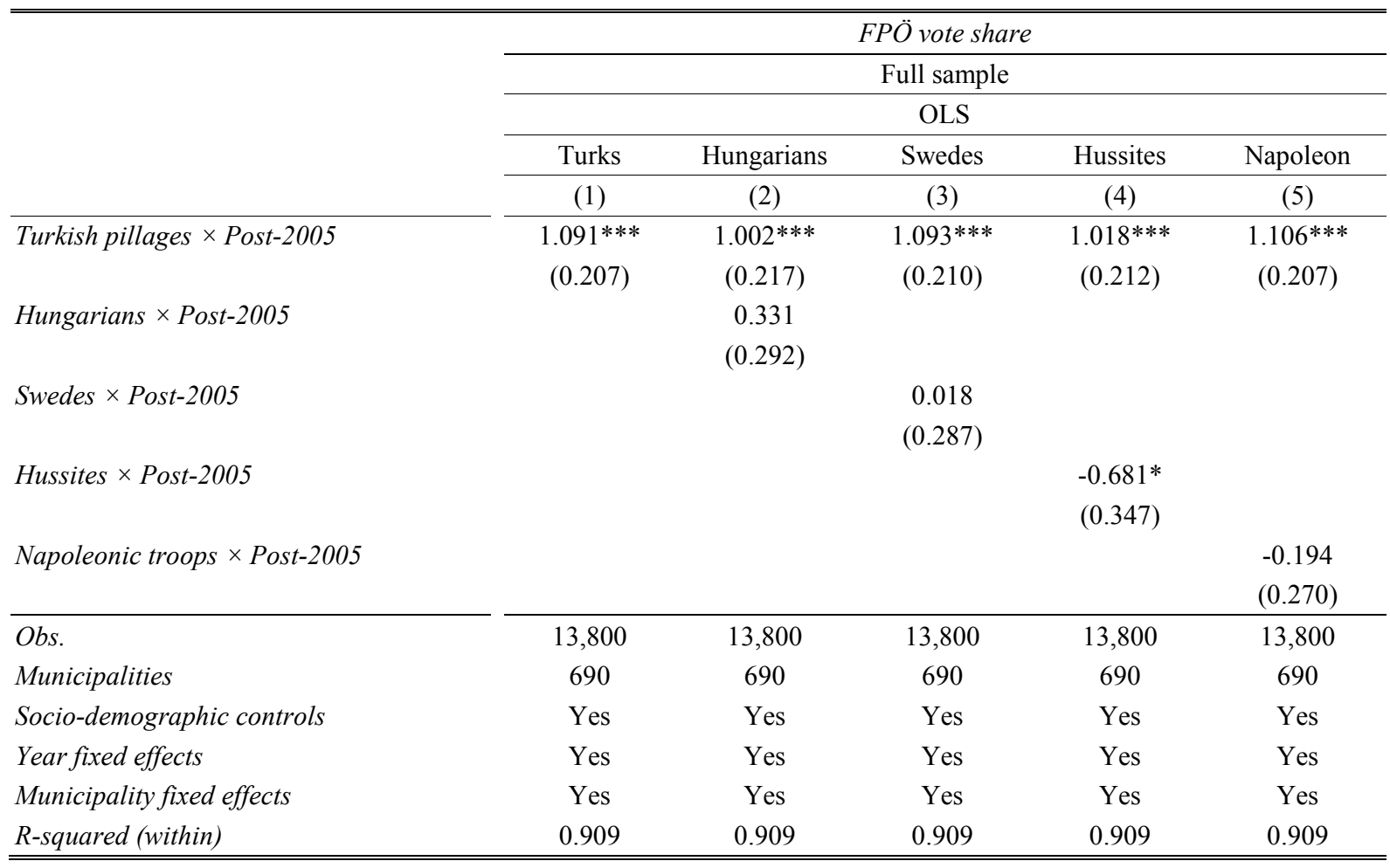

Notes: The dependent variable is the FPÖ vote share at the level of 690 East Austrian municipalities. Column (1) replicates the baseline results. In columns (2) to (5), we add interaction terms of municipalities with a record of atrocities from other foreign forces. Significance levels (standard errors clustered at municipality level): *** 0.01 , $* * 0.05, * 0.10$.

\subsection{Other right-wing parties}

We test whether the effects show up when we consider other contemporaneous Austrian rightwing parties that never campaigned against Turks. The massive defeat of the FPÖ in the 2002 national election led to internal disputes about the future orientation of the party. A group of politicians led by Heinz-Christian Strache wished to strengthen the anti-immigration profile of the FPÖ. In 2005, Jörg Haider resigned and formed a new right-wing party, the Alliance for the Future of Austria (Bündnis Zukunft Österreich, BZÖ). As Luther (2009) notes, the manifesto of the BZÖ significantly overlapped with the manifesto of the FPÖ, but their campaigns sharply contrast. Most importantly, the BZÖ did not conduct any anti-Turkish and anti-Muslim election campaigns. By contrast, Haider was even heavily in favor of the Arab world, as described in Section 3. Thus, two populist right-wing parties, which, however, substantially differ on the 
issue of anti-Turkish and anti-Muslim campaigning, compete in the elections. In 2013, Team Stronach was founded by the billionaire Frank Stronach as a third right-wing party. Team Stronach especially recruits former BZÖ politicians and does also not conduct anti-Turkish campaigns.

TABLE 10. OTHER RIGHT-WING PARTIES

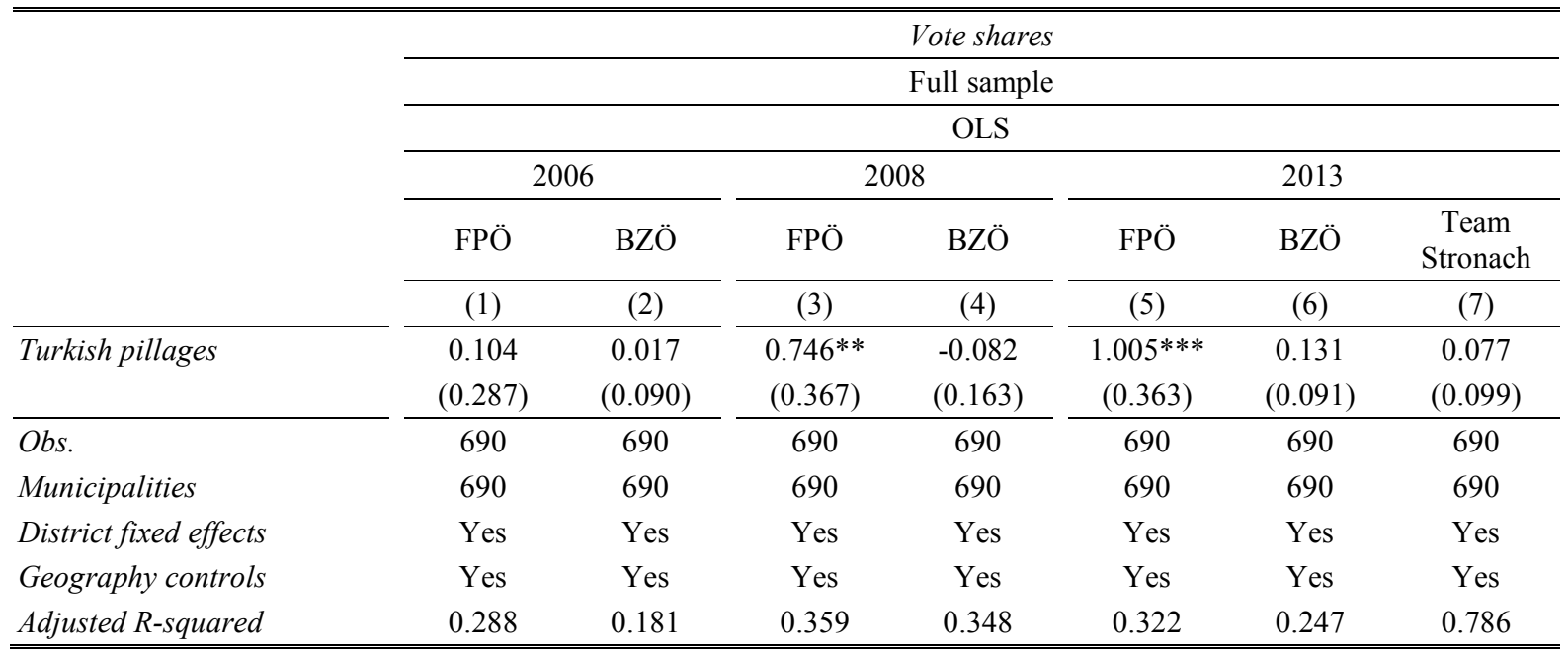

Notes: The dependent variable is the vote share for right-wing and populist parties at the level of 690 East Austrian municipalities. Significance levels (robust standard errors): $* * * 0.01, * * 0.05, * 0.10$.

We exploit the split of the extreme right-wing camp. We test whether the vote shares for the newly founded BZÖ and later for Team Stronach differ among pillaged and non-pillaged municipalities. As outlined above, neither the BZÖ nor Team Stronach conducted anti-Turkish campaigns; thus, we do not expect to observe a significant effect. Table 10 (columns 1 to 6) compares the effects on the FPÖ vote shares to the effects on the BZÖ vote shares in crosssections of the national elections in 2006, 2008, and 2013. In addition, column (7) shows the potential effects for the billionaire-founded right-wing party Team Stronach. However, in sharp contrast to the FPÖ vote shares, neither vote shares for the right-wing BZÖ nor for Team Stronach differ among pillaged and non-pillaged municipalities. Voters could select from three almost similar right-wing parties, but the effects emerge only in FPÖ vote shares. Thus, only the FPÖ, as the sole right-wing party to refer to anti-Turkish sentiments, gained additional support 
in municipalities with a record of Turkish atrocities. Voters in once pillaged municipalities are thus prone to an information bias; they treat the campaign information differently and are in turn more willing to vote for the FPÖ but not for other right-wing parties that do not conduct anti-Turkish or anti-Muslim campaigns. This finding indicates that the channel of increasing right-wing populism per se does not explain the voting differentials between pillaged and nonpillaged municipalities.

\subsection{Other periods of radicalization}

Political campaigning based on the sieges of Vienna was already an issue in the 1920s and 1930s, when political radicalization and polarization surged. In these decades, ethnicity became a major political issue as well. The Austrian right-wing camp - including the Nazi party (NSDAP) - used the Turkish sieges for its propaganda. In its view, the exemption of Vienna from the Turkish threat was an indication of the superiority and the unity of the Aryan race (Barbarics-Hermanik 2013). Furthermore, the Catholic-conservative Austro-Fascist government used the 250th anniversary of Siege II in 1933 for its propaganda for a united Austrian nation rooted in Christianity (Suppanz 2013). However, both the right-wing camp and the Catholic-conservative Austro-Fascist regime interpreted the sieges of Vienna as an example of the threat from the East, especially Bolshevism. In sharp contrast to the modern FPÖ period, neither political camp however conducted anti-Turkish campaigns (Hadler 2013, Suppanz 2013).

We test whether the vote shares in the last democratic national election before Austro-Fascism and the annexation of Austria by Nazi Germany differ between pillaged and non-pillaged municipalities. Table 11 shows cross-sectional results for the 1930 national election for the entire right-wing camp (column 1), for the Austrian branch of the NSDAP alone (column 2), for the Catholic Conservatives (the latter Fascist rulers) (column 3), and for the never-campaigning 
Social Democrats (column 4). ${ }^{35}$ We find no significant difference in vote shares for the competing parties for the election of 1930 among the pillaged and non-pillaged municipalities. This corroborates our findings for other more contemporary right-wing parties (see Section 6.5). Political campaigns that refer to the same collective memory but with no contemporaneous link to Turkish or Muslim stereotypes were thus not sufficient to allow the collective memory to become visible.

TABLE 11. OTHER PERIODS OF RADICALIZATION

\begin{tabular}{|c|c|c|c|c|}
\hline & \multicolumn{4}{|c|}{ Vote shares 1930} \\
\hline & \multicolumn{4}{|c|}{ Full sample } \\
\hline & \multicolumn{4}{|c|}{ OLS } \\
\hline & \multicolumn{2}{|c|}{ Right-wing parties (FPÖ equivalent) } & \multirow{2}{*}{$\begin{array}{c}\text { Catholic Conserva- } \\
\text { tives (ÖVP equiva- } \\
\text { lent) }\end{array}$} & \multirow{2}{*}{$\begin{array}{l}\text { Social Democrats } \\
\text { (SPÖ equivalent) }\end{array}$} \\
\hline & Entire camp & NSDAP & & \\
\hline & (1) & (2) & (3) & (4) \\
\hline \multirow[t]{2}{*}{ Turkish pillages } & -0.716 & -0.238 & -0.322 & 0.961 \\
\hline & $(1.183)$ & $(0.316)$ & $(2.099)$ & $(1.734)$ \\
\hline Obs. & 690 & 690 & 690 & 690 \\
\hline Municipalities & 690 & 690 & 690 & 690 \\
\hline District fixed effects & Yes & Yes & Yes & Yes \\
\hline Geography controls & Yes & Yes & Yes & Yes \\
\hline Adjusted $R$-squared & 0.271 & 0.363 & 0.274 & 0.339 \\
\hline
\end{tabular}

Notes: The dependent variable is the vote share in the national election of 1930 for the three political camps in Austria (right wing, Catholic Conservatives, and Social Democrats) at the level of 690 East Austrian municipalities. Columns (1) and (2) show vote share differences between pillaged and non-pillaged municipalities for the entire right-wing camp and separately for the NSDAP. Column (3) shows vote share differences for the Catholic Conservatives, column (4) for the Social Democrats. Significance levels (robust standard errors): *** 0.01, ** $0.05, * 0.10$.

\section{Mechanism}

In the previous section, we show that two main conditions must be met to activate any effect: a local historical record of foreign atrocities and a campaign that directly addresses the stereotypes of these foreigners. We now investigate the mechanisms at work. We assess the origins of the gains in FPÖ vote shares by investigating other parties (Section 6.7) and heterogeneous effects among different municipal characteristics.

\footnotetext{
${ }^{35}$ In contrast to the NSDAP and the Catholic conservatives, we find no evidence that the Social Democrats used the sieges for their propaganda.
} 


\subsection{Other parties and voter turnout}

When FPÖ vote shares increase in formerly pillaged municipalities, the vote shares for other parties must decrease accordingly. We apply our baseline difference-in-differences model to the other two main political camps in Austria - the conservative ÖVP and the left-wing camp, which consists of the social-democratic SPÖ and the Green Party.

TABLE 12. OTHER PARTIES AND VOTER TURNOUT

\begin{tabular}{|c|c|c|c|c|}
\hline & \multicolumn{4}{|c|}{ Vote shares } \\
\hline & \multicolumn{4}{|c|}{ Full sample } \\
\hline & \multicolumn{4}{|c|}{ OLS } \\
\hline & FPÖ & ÖVP & SPÖ/Greens & Voter turnou \\
\hline & $(1)$ & $(2)$ & (3) & $(4)$ \\
\hline \multirow[t]{2}{*}{ Turkish pillages $\times$ Post -2005} & $1.091 * * *$ & -0.542 & $-1.039 * * *$ & -0.254 \\
\hline & $(0.207)$ & $(0.347)$ & $(0.345)$ & $(0.213)$ \\
\hline Obs. & 13,800 & 13,800 & 13,800 & 13,800 \\
\hline Municipalities & 690 & 690 & 690 & 690 \\
\hline Socio-demographic controls & Yes & Yes & Yes & Yes \\
\hline Year fixed effects & Yes & Yes & Yes & Yes \\
\hline Municipality fixed effects & Yes & Yes & Yes & Yes \\
\hline$R$-squared (within) & 0.909 & 0.849 & 0.494 & 0.852 \\
\hline
\end{tabular}

Notes: The dependent variable is the vote share for the respective parties or voter turnout at the level of 690 East Austrian municipalities. Column (1) replicates the baseline results for the FPÖ. Columns (2) to (4) show difference-in-differences estimates for the conservative ÖVP (column (2)), for the Social Democrats (SPÖ) and the Green Party (column (3)) and for voter turnout (column (4)). Significance levels (standard errors clustered at municipality level): $* * * 0.01, * * 0.05, * 0.10$.

Table 12 shows the results. We observe that the increase in FPÖ vote shares in pillaged municipalities comes with a one-to-one reduction in vote shares of the left-wing camp. The conservative ÖVP, however, is not affected. We conclude that the FPÖ attracts blue-collar voters, particularly in the once pillaged municipalities, through its anti-Turkish campaigns. This finding is fully consistent with prior findings (Potrafke and Roesel 2016). The FPÖ relies on interventionist economic and generous social policies (at least for Austrian citizens) that target bluecollar voters and welfare state recipients (Luther 2009). We also test whether increases in FPÖ vote shares might reflect changes in voter turnout in formerly pillaged municipalities. The results in column (4) allow us to reject this hypothesis. 


\subsection{Heterogeneous effects}

In Table 13, we examine whether the effects differ among municipal characteristics. We split the full sample into municipalities below the median (column 1) and above the median (column 2) in terms of different socio-demographic and geographic variables. We rely on the last census data of 2001 prior to the FPÖ anti-Turkish campaigns. We then estimate our baseline model for the two subsamples separately.

The upper part of Table 13 shows the heterogeneous activation effects by socio-demographic variables. We find stronger effects in smaller municipalities (in terms of electorate) and in more rural municipalities (settlement density, share of employment in agriculture). These findings indicate that the local memory is more pronounced in small rural communities, which in turn enables the FPÖ campaigns to shift voters' recognition more easily. This finding is confirmed when we consider the local embeddedness of the population. We estimate the activation effects according to the share of out-commuters, which proxies the embeddedness of residents in municipalities' daily life. We find stronger effects in municipalities with a lower share of outcommuters, which corroborates that the collective memory is likely to be a function of local embeddedness. Activation is also stronger in municipalities with a higher share of employment in industry and with a higher share of unemployed people. This is consistent with the findings in Section 6.7 that gains in FPÖ vote shares come at the cost of the blue-collar-oriented leftwing camp (see also Luther 2009). Municipalities below and above the median in terms of the population share of foreigners do not show considerable differences in activation patterns. In contrast, the FPÖ gains somewhat more electoral support in pillaged municipalities if there is a higher share of Turkish foreigners and a higher share of Muslim residents. The effects might be intensified by local contacts with Turkish foreigners and Muslim residents (see Halla, Wagner and Zweimüller 2016). 


\begin{tabular}{|c|c|c|}
\hline \multirow{5}{*}{ Turkish pillages $\times$ Post -2005} & \multicolumn{2}{|c|}{ FPÖ vote share } \\
\hline & \multicolumn{2}{|c|}{ Subsamples by medians } \\
\hline & \multicolumn{2}{|c|}{ OLS } \\
\hline & $<$ Median & $\geq$ Median \\
\hline & (1) & (2) \\
\hline \multicolumn{3}{|l|}{ Socio-demographics } \\
\hline \multirow[t]{2}{*}{ Electorate $(\log )$} & $1.432 * * *$ & $0.747 * *$ \\
\hline & $(0.298)$ & $(0.290)$ \\
\hline \multirow[t]{2}{*}{ Settlement density } & $1.299 * * *$ & $0.576^{*}$ \\
\hline & $(0.267)$ & $(0.311)$ \\
\hline \multirow[t]{2}{*}{ Population share foreigners } & $0.947 * * *$ & $1.031 * * *$ \\
\hline & $(0.277)$ & $(0.324)$ \\
\hline \multirow[t]{2}{*}{ Population share Turkish foreigners } & $0.812 * * *$ & $0.958 * * *$ \\
\hline & $(0.282)$ & $(0.301)$ \\
\hline \multirow[t]{2}{*}{ Population share Muslims } & $0.785 * * *$ & $1.150 * * *$ \\
\hline & $(0.285)$ & $(0.304)$ \\
\hline \multirow[t]{2}{*}{ Share agriculture } & $0.751 * *$ & $1.064^{* * *}$ \\
\hline & $(0.316)$ & $(0.260)$ \\
\hline \multirow[t]{2}{*}{ Share industry } & $0.977 * * *$ & $1.213 * * *$ \\
\hline & $(0.302)$ & $(0.275)$ \\
\hline \multirow[t]{2}{*}{ Population share unemployed } & $0.854 * * *$ & $1.391 * * *$ \\
\hline & $(0.285)$ & $(0.286)$ \\
\hline \multirow[t]{2}{*}{ Population share out-commuters } & $1.160 * * *$ & $0.912 * * *$ \\
\hline & $(0.299)$ & $(0.299)$ \\
\hline \multicolumn{3}{|l|}{ Geography } \\
\hline \multirow[t]{2}{*}{ Distance to Vienna } & $0.589^{*}$ & $1.357 * * *$ \\
\hline & $(0.323)$ & $(0.295)$ \\
\hline \multirow[t]{2}{*}{ Distance to external border } & $1.143 * * *$ & $1.171^{* * *}$ \\
\hline & $(0.292)$ & $(0.268)$ \\
\hline \multirow[t]{2}{*}{ Distance to highway } & $0.532 *$ & $1.403 * * *$ \\
\hline & $(0.311)$ & $(0.277)$ \\
\hline Obs. & 13,800 & 13,800 \\
\hline Socio-demographic controls & Yes & Yes \\
\hline Year fixed effects & Yes & Yes \\
\hline Municipality fixed effects & Yes & Yes \\
\hline
\end{tabular}

Notes: The dependent variable is the FPÖ vote share at the level of 690 East Austrian municipalities. In columns (1) and (2), we split the sample into municipalities below and above the median of the respective socio-demographic and geographic variable. Significance levels (standard errors clustered at municipality level): *** 0.01 , ** $0.05, * 0.10$.

The lower part of Table 13 shows the activation effects for subsamples by municipal geographic characteristics. Municipalities that are farther from Vienna and farther from a highway exhibit larger effects. This corroborates our previous findings that more remote and rural communities are likely to be more aware of the collective memory and therefore more susceptible to the FPÖ campaigns. By contrast, distance to an external border makes no difference. 


\section{Conclusion}

This paper shows that political campaigns that use stereotypes of ethnic and religious minorities can be highly effective when the campaigning encounters a collective memory. We link Turkish atrocities and pillages during the sieges of Vienna in the 16th and 17th centuries to the presentday vote shares of the Austrian right-wing FPÖ. The FPÖ began to campaign against Turkish foreigners in 2005. Both the collective memory of the sieges and the campaigns transmit stereotypes about the targeted group, such as an inherent cultural propensity to violence or an aim to dominate and oppress the local culture. We show that FPÖ vote shares increased in municipalities that were exposed to Turkish atrocities compared to non-affected municipalities after the campaigning began in 2005 but not before. Our results show that the long-gone past can be activated and "pop up" in current socio-economic variables after remaining invisible for decades or even centuries. Campaigns thus may act as tipping points to catalyze history in a nonlinear fashion. Furthermore, political parties can materialize history, which in turn increases vote shares. However, we also show that activation requires two necessary conditions: the presence of a collective memory and a trigger of activation.

Our results carry two important messages for both political scientists and economists. First, voters seem to be sensitive to information. Our findings suggest that campaigning leads to differences in recognition, which is dependent on voters' embeddedness in communities. While this finding is not completely new, we show that the recognition of stereotypes or platitudes is spatially dependent. This might have been an issue in the EU membership referendum in the United Kingdom in 2016 as well as in Donald Trump's 2016 presidential campaigns against Mexicans and Muslims. Second, we show that the long gone and arguably irrelevant past can emerge in present-day socio-economic figures after remaining irrelevant or even forgotten for decades and centuries. This is an important message for studies that describe the (spatial) per- 
sistence of social norms and attitudes. In our case, a simple cross-sectional analysis of the election outcomes in 2013 would mask the non-linear evolution of the pillaging effect that was never observed before 2005 but was then activated by campaigning. We learn that the activated past may lead to a spurious persistence. Future research in this field should focus on this nonlinearity and may further exploit the time-variant triggers of effects.

\section{References}

Acemoglu, Daron, Simon Johnson, and James A. Robinson (2001), "The colonial origins of comparative development: an empirical investigation," American Economic Review, 91 (5), 1369-1401.

Acemoglu, Daron, Tarek A. Hassan, and James A. Robinson (2011), "Social Structure and Development: A Legacy of the Holocaust in Russia," Quarterly Journal of Economics, 126 (2), 895-946.

Adena, Maja, Ruben Enikolopov, Maria Petrova, Veronica Santarosa, and Ekaterina Zhuravskaya (2015), "Radio and the Rise of Nazis in Pre-War Germany," Quarterly Journal of Economics, 130 (4), 1885-1939.

Alesina, Alberto, and Nicola Fuchs-Schündeln (2007), "Goodbye Lenin (or Not?): The Effect of Communism on People,” American Economic Review, 97 (4), 1507-1528.

Angrist, Joshua D., and Jörn-Steffen Pischke (2010), Mostly Harmless Econometrics: An Empiricist's Companion, (Oxford and Princeton: Princeton University Press).

Assmann, Jan (1988), „Kollektives Gedächtnis und kulturelle Identität,“ in: Kultur und Gedächtnis, Assmann, Jan, and Tonio Hölscher, eds. (Frankfurt am Main: Suhrkamp), 919.

Arzheimer, Kai (2009), "Contextual factors and the extreme right vote in Western Europe, 1980-2002," American Journal of Political Science 53 (2), 259-275.

Arzheimer, Kai (2017), “Explaining Electoral Support for the Radical Right,” in: The Oxford Handbook of the Radical Right, Rydgren, Jens, ed. (Oxford: Oxford University Press), forthcoming. 
Barbarics-Hermanik, Zsuzsa (2013), „Türkensturz à la Graz? Motive und Bilder aus dem `Türkengedächtnis` der stierischen Hauptstadt,“ in: Geschichtspolitik und Türkenbelagerung, Feichinger, Johannes, and Johann Heiss, eds. (Wien Mandelbaum), 211-234.

Basten, Christoph, and Frank Betz (2013), "Beyond Work Ethic: Religion, Individual, and Political Preferences," American Economic Journal: Economic Policy, 5 (3), 67-91.

Becker, Sascha O., Katrin Boeckh, Christa Hainz, and Ludger Woessmann (2016), "The Empire Is Dead, Long Live the Empire! Long-Run Persistence of Trust and Corruption in the Bureaucracy," Economic Journal, 126 (590), 40-74.

Bordalo, Pedro, Nicola Gennaioli, and Andrei Shleifer (2017), "Memory, Attention and Choice," mimeo, University of Oxford, Oxford.

Bordalo, Pedro, Katherine Coffman, Nicola Gennaioli, and Andrei Shleifer (2016), "Stereotypes," The Quarterly Journal of Economics, 131 (4), 1753-1794.

Brosig-Koch, Jeanette, Christoph Helbach, Axel Ockenfels, and Joachim Weimann (2011), "Still different after all these years: Solidarity behavior in East and West Germany," Journal of Public Economics, 95 (11-12), 1373-1376.

Broucek, Peter (1989), Der Schwedenfeldzug nach Niederösterreich 1645/46, Heeresgeschichtliches Museum/ Militärwissenschaftliches Institut, ed. (Vienna: Österreichischer Bundesverlag).

Broucek, Peter, Erich Hillbrand, and Fritz Vesely (1983), Historischer Atlas zur zweiten Türkenbelagerung. Wien 1683, (Vienna: Deuticke).

Caicedo, Felipe V. (2014), “The Mission: Human Capital Transmission, Economic Persistence and Culture in South America," mimeo, Universitat Pompeu Fabra, Barcelona.

Card, David, Christian Dustmann, and Ian Preston (2012), "Immigration, Wages, And Compositional Amenities," Journal of the European Economic Association, 10 (1), 78-119.

Chetty, Raj, Adam Looney, and Kori Kroft (2009), "Salience and Taxation: Theory and Evidence," American Economic Review, 99 (4), 1145-1177.

Clam Martinic, Georg (1991), Österreichisches Burgenlexikon: Burgen und Ruinen, Ansitze, Schlösser und Palais (Linz Landesverlag).

Conley, Timothy G. (1999), "GMM Estimation with Cross Sectional Dependence," Journal of Econometrics, 92 (1), 1-45. 
Conley, Timothy G. (2008), "Spatial Econometrics", in: Durlauf, Steven. N. and Lawrence E. Blume, eds., The New Palgrave Dictionary of Economics, Second Edition (Palgrave Macmillan UK).

Da Silveira, Bernardo S., and João M. P. De Mello (2011), "Campaign advertising and election outcomes: Quasi-natural experiment evidence from gubernatorial elections in Brazil," Review of Economic Studies, 78 (2), 590-612.

Dallinger, Silvia (2013), „Was macht ein Pascha auf einem Esel? Die zweite Wiener ,Türkenbelagerung' als gegenwärtige Vergangenheit,“ in: Geschichtspolitik und Türkenbelagerung, Feichinger, Johannes, and Johann Heiss, eds. (Wien: Mandelbaum), 168-191.

Dell, Melissa (2010), “The Persistent Effects of Peru's Mining Mita,” Econometrica, 78 (6), 1863-1903.

DellaVigna, Stefano, Ruben Enikolopov, Vera Mironova, Maria Petrova, and Ekaterina Zhuravskaya (2014), "Cross-Border Media and Nationalism: Evidence from Serbian Radio in Croatia," American Economic Journal: Applied Economics, 6 (3), 103-132.

DellaVigna, Stefano, and Ethan Kaplan (2007), “The Fox News effect: Media bias and voting," Quarterly Journal of Economics, 122 (3), 1187-1234.

DellaVigna, Stefano, and Joshua M. Pollet (2009), "Investor Inattention and Friday Earnings Announcements," Journal of Finance, 64 (2), 709-749.

Dustmann, Christian, and Ian P. Preston (2007), "Racial and Economic Factors in Attitudes to Immigration," B.E. Journal of Economic Analysis \& Policy, 7 (1), 1-41.

Egger, Rainer (1964), Das Gefecht bei Dürnstien-Loiben 1805, Heeresgeschichtliches Museum/ Militärwissenschaftliches Institut, ed., (Vienna: Österreichischer Bundesverlag).

Enikolopov, Ruben, Maria Petrova, and Ekaterina Zhuravskaya (2011), "Media and Political Persuasion: Evidence from Russia," American Economic Review, 101 (7), 3253-3285.

Erickson, Edgar L. (1950), "The zoning of Austria," Annals of the American Academy of Political and Social Science, 267 (1), 106-113.

Eugster, Beatrix, Rafael Lalive, Andreas Steinhauer, and Josef Zweimüller (2011), "The Demand for Social Insurance: Does Culture Matter?," Economic Journal, 121 (556), 413448. 
Facchini, Giovanni, and Anna M. Mayda (2009), "Does the welfare state affect individual attitudes toward immigrants? Evidence across countries," Review of Economics and Statistics, 91 (2), 295-314.

Fisman, Raymond, Yasushi Hamao, and Yongxiang Wang (2014), "The Impact of Interstate Tensions on Economic Exchange: Evidence from Shocks to Sino-Japanese Relations,” Review of Financial Studies, 27 (9), 2626-2660.

Fouka, Vasiliki, and Hans-Joachim Voth (2016), "Reprisals Remembered: German-Greek Conflict and Car Sales during the Euro Crisis,” Working Paper, University of Zurich.

FPÖ Sollenau (2010), Freiheitlicher Gemeindekurier Sollenau, Heft 3/2010.

Funke, Manuel, Moritz Schularickb, and Christoph Trebesch (2016), "Going to Extremes: Politics after Financial Crisis, 1870-2014,” European Economic Review, 88, 227-260.

Gennaioli, Nicola, and Andrei Shleifer (2010), "What Comes to Mind," Quarterly Journal of Economics, 125 (4), 1399-1433.

Gentzkow, Matthew (2006), "Television and voter turnout," Quarterly Journal of Economics, 121 (3), 931-972.

Gentzkow, Matthew, Jesse Shapiro, and Michael Sinkinson (2011), “The Effect of Newspaper Entry and Exit on Electoral Politics," American Economic Review, 101 (7), 2980-3018.

Gerber, Alan S., James G. Gimpel, Donald P.,Green, and Daron R. Shaw (2011), "How large and long-lasting are the persuasive effects of televised campaign ads? Results from a randomized field experiment," American Political Science Review, 105 (1), 135-150.

Gerber, Alan S., Dean Karlan, and Daniel Bergan (2009), "Does the media matter? A field experiment measuring the effect of newspapers on voting behavior and political opinions," American Economic Journal: Applied Economics, 1 (2), 35-52.

Gerhartl, Gertrud (1981), Die Niederlage der Türken am Steinfeld 1532, Heeresgeschichtliches Museum/ Militärwissenschaftliches Institut, ed. (Vienna: Österreichischer Bundesverlag).

Gerhartl, Gertrud ((1983), Belagerung und Entsatz von Wien 1683, Heeresgeschichtliches Museum/ Militärwissenschaftliches Institut, ed. (Vienna: Österreichischer Bundesverlag).

Gingrich, Andre (2003), „Grenzmythen des Orientalismus. Die islamische Welt in Öffentlichkeit und Volkskultur Mitteleuropas,“ in: Orientalische Reise. Malerei und Exotik im 
späten 19. Jahrhundert, Mayr-Oehring, Erika, and Andre Gingrich, eds. (Wien Historisches Museum der Stadt Wien), 110-129.

Glaeser, Edward L., and Andrei Shleifer (2002), "Legal Origins," Quarterly Journal of Economics, 117 (4), 1193-1230.

Guiso, Luigi, Paola Sapienza, and Luigi Zingales (2016), “Long Term Persistence,” Journal of the European Economic Association, 14 (6), 1401-1436.

Gutkas, Karl (1973), Geschichte des Landes Niederösterreich (St. Pölten: Niederösterreichisches Pressehaus Druck- und VerlagsgesmbH).

Hadler, Simon (2013), „Helden, Verteidiger, Opfer: Beispiele lokaler Erinnerung in Niederösterreich,“ in: Geschichtspolitik und Türkenbelagerung, Feichinger, Johannes, and Johann Heiss, eds. (Wien: Mandelbaum), 192-210.

Hainmueller, Jens, and Michael J. Hiscox (2007), "Educated Preferences: Explaining Attitudes Toward Immigration in Europe,” International Organization, 61 (02), 399-442.

Hainmueller, Jens, and Michael J. Hiscox (2010), “Attitudes toward Highly Skilled and Lowskilled Immigration: Evidence from a Survey Experiment," American Political Science Review, 104 (01), 61-84.

Hainmueller, Jens, Michael J. Hiscox, and Yotam Margalit.(2015), "Do concerns about labor market competition shape attitudes toward immigration? New evidence;" Journal of International Economics, 97 (1), 193-207.

Halbwachs, Maurice (1985), Das Gedächtnis und seine sozialen Bedingungen, (Frankfurt am Main Suhrkamp).

Hall, Robert E., and Charles I. Jones (1999), "Why do Some Countries Produce so Much More Output per Worker Than Others?," Quarterly Journal of Economics, 114 (1), 83-116.

Halla, Martin, Alexander F. Wagner, and Josef Zweimüller (2016), "Does Immigration into Their Neighborhood Incline Voters Toward the Extreme Right: The Case of the Freedom Party of Austria," Journal of the European Economic Association, forthcoming.

Hanson, Gordon H., Kenneth Scheve, and Matthew J. Slaughter (2007), "Public finance and individual preferences over globalization strategies," Economics and Politics, 19 (1), 133. 
Hilton, James L., and William von Hippel (1996), “Stereotypes,” Annual Review of Psychology, 47, 237-271.

Hornbeck, Richard, and Suresh Naidu (2014), "When the Levee Breaks: Black Migration and Economic Development in the American South," American Economic Review, 104 (3), 963-990.

Hummelberger, Walter (1983), Wiens erste Belagerung durch die Türken 1529, Heeresgeschichtliches Museum/ Militärwissenschaftliches Institut, ed. (Vienna: Österreichischer Bundesverlag).

Ignazi, Piero (2003), Extreme right parties in Western Europe (Oxford: Oxford University Press).

Kahneman, Daniel, and Amos Tversky (1982), Judgment Under Uncertainty: Heuristics and Biases (New York: Cambridge University Press).

Kendall, Chad, Tommaso Nannicini, and Francesco Trebbi (2015), "How Do Voters Respond to Information? Evidence from a Randomized Campaign," American Economic Review, 105 (1), 322-353.

Knight, Robert (1992), "Haider, the Freedom Party and the Extreme Right in Austria," Parliamentary Affairs, 45 (3), 285-299.

Lacom, Harald (2009), Niederösterreich brennt! Tatarisch-osmanische Kampfeinheiten 1683 (Vienna: Stöhr).

Luther, Kurt R. (2000), “Austria: a democracy under threat from the freedom party?," Parliamentary Affairs, 53 (3), 426-442..

Luther, Kurt R. (2009), “The Revival of the Radical Right: The Austrian Parliamentary Election of 2008”, West European Politics, 32 (5), 1049-1061.

Madestam, Andreas, Daniel Shoag, Stan Veuger and David Yanagizawa-Drott (2013), "Do Political Protests Matter? Evidence from the Tea Party Movement," Quarterly Journal of Economics, 128 (4), 1633-1685.

Magocsi, Paul R. (2002), Historical Atlas of East Central Europe (Seattle, WA: University of Washington Press). 
Mayda, Anna M. (2006), "Who is against immigration? A cross-country investigation of individual attitudes toward immigrants," Review of Economics and Statistics, 88 (3), 510 530.

Mudde, Cas (2013), “Three decades of Populist Radical Right Parties in Europe: So What?”, European Journal of Political Research, 52 (1), 1-19.

Mullainathan, Sendhil (2002), A Memory-Based Model Of Bounded Rationality, Quarterly Journal of Economics, 117 (3), 735-774.

Nunn, Nathan (2008), “The Long-Term Effects of Africa's Slave Trades," Quarterly Journal of Economics, 123 (1), 139-176.

Nunn, Nathan (2010), "Religious Conversion in Colonial Africa," American Economic Review: Papers \& Proceedings, 100 (2), 147-152.

Nunn, Nathan, and Leonard Wantchekon (2011), "The Slave Trade and the Origins of Mistrust in Africa," American Economic Review, 101 (7), 3221-3252.

Ochsner, Christian, and Felix Roesel (2016), "Migrating Extremists," CESifo Working Paper No. 5799.

Oto-Peralías, Daniel and Diego Romero-Ávila (2017). "Historical Frontiers and the Rise of Inequality. The Case of the Frontier of Granada," Journal of the European Economic Association, forthcoming.

Ockenfels, Axel, and JoachimWeimann (1999), "Types and patterns: an experimental EastWest-German comparison of cooperation and solidarity," Journal of Public Economics $71(2), 275-287$.

Petrin, Silvia (1982), Der österreichische Hussitenkrieg 1420-1434, Heeresgeschichtliches Museum/ Militärwissenschaftliches Institut, ed. (Vienna: Österreichischer Bundesverlag).

Pfeifer, Judith (2013), „1683 revisted: Die ,Türkenbelagerung' in österreichischen Zeitungen 1955-2010,“ in: Der erinnerte Feind: Kritische Studien zur Türkenbelagerung, Heiss, Johann, and Johannes Feichinger, eds. (Wien: Mandelbaum), 211-242.

Pope, Devin G. (2009), "Reacting to Rankings: Evidence from "America's Best Hospitals",, Journal of Health Economics, 28 (6), 1154-1165. 
Potrafke, Niklas, and Felix Roesel (2016), “Opening Hours of Polling Stations and Voter Turnout: Evidence from a Natural Experiment," CESifo Working Paper No. 6036.

Rauchensteiner, Manfried (1994), Die Schlacht von Aspern am 21. und 22. Mai 1809, Heeresgeschichtliches Museum/ Militärwissenschaftliches Institut, ed. (Vienna: Österreichischer Bundesverlag).

Rázsó, Gyula (1973), Die Feldzüge des Königs Matthias Corvinus in Niederösterreich 14771490, Heeresgeschichtliches Museum/ Militärwissenschaftliches Institut, ed. (Vienna: Österreichischer Bundesverlag).

Rydgren, Jens (2008), “Immigration sceptics, xenophobes or racists? Radical right-wing voting in six West European countries," European Journal of Political Research, 47 (6), 737 765.

Rydgren, Jens (2011), “A legacy of 'uncivicness'? Social capital and radical right-wing populist voting in Eastern Europe," Acta Politica, 46 (2), 132-157.

Satyanath, Shanker, Nico Voigtländer, and Hans-Joachim Voth (2017), "Bowling for Fascism: Social Capital and the Rise of the Nazi Party in Weimar Germany, 1919-33," Journal of Political Economy, forthcoming.

Schelling, Thomas C. (1978), Micromotives and Macrobehavior (New York: W. W. Norton).

Scheve, Kenneth F., and Matthew J. Slaughter (2001), "Labor market competition and individual preferences over immigration policy," Review of Economics and Statistics, 83 (1), $133-145$.

Schindler, David, and Mark Westcott (2015), "Shocking Racial Attitudes: The Cultural Legacy of Black GIs in Europe" (mimeo, University of Munich, Munich).

Spolaore, Enrico, and Romain Wacziarg (2013), "How Deep Are the Roots of Economic Development?," Journal of Economic Literature, 51 (2), 325-369.

Staeuber, Roland (1974), Der Verbund der Unabhängigen (VdU) und die Freiheitliche Partei Österreichs (FPÖ): Eine Untersuchung über die Problematik des Deutschnationalismus als Einigungsfaktor einer politischen Partei in Österreich seit 1945 (St. Gallen: ok organisation kolb).

Steinmayr, Andreas (2016), "Exposure to Refugees and Voting for the Far-Right: (Unexpected) Results from Austria,” WIFO Working Papers No. 514/2016. 
Stoye, John (2007), The Siege of Vienna: The Last Great Trial Between Cross \& Crescent (New York Pegasus Books).

Suppanz, Werner (2013), „An der „Kulturfront des Abendlandes“: Diskurse und Inszinierung der „Türkenabwehr“ im Austrofaschismus,“ in: Der erinnerte Feind: Kritische Studien zur Türkenbelagerung, Heiss, Johann, and Johannes Feichinger, eds. (Wien: Mandelbaum), 162-184.

Tabellini, Guido (2008a), "Presidential Address Institutions and Culture," Journal of the European Economic Association, 6 (2-3), 255-294.

Tabellini, Guido (2008b), “The Scope of Cooperation: Values and Incentives," Quarterly Journal of Economics, 123 (3), 905-50.

Tabellini, Guido (2010), "Culture and Institutions: Economic Development in the Regions of Europe," Journal of the European Economic Association, 8 (4), 677-716.

Tallett, Frank (1992), War and society in early-modern Europe, 1495-1715 (London: Routledge).

Voigtländer, Nico, and Hans-Joachim Voth (2012), "Persecution Perpetuated: The Medieval Origins of Anti-Semitic Violence in Nazi Germany," Quarterly Journal of Economics, 127 (3), 1339-1392.

Voigtländer, Nico, and Hans-Joachim Voth (2015), "Nazi indoctrination and anti-Semitic beliefs in Germany," Proceedings of the National Academy of Sciences of the United States of America, 112 (26), 7931-7936.

Witzeling, Johanna (2013), „'Türkenbelagerungen’ in der Schule? Zur Vermittlung von Geschichtsbildern über 1683 im Wiener Pflichtschulunterricht,“ in: Der erinnerte Feind: Kritische Studien zur Türkenbelagerung, Heiss, Johann, and Johannes Feichinger, eds. (Wien: Mandelbaum), 185-210.

Young, Hobart P. (2015), “The Evolution of Social Norms," Annual Review of Economics, 7, $359-387$. 


\section{Supplementary material}

\section{A. Coding of Turkish atrocity records}

Historical and contemporaneous books precisely describe the geopolitical background of the sieges of Vienna and provide a day-to-day sequence of these attacks from a Viennese perspective (e.g., Broucek, Hillbrand and Vesely 1983, Stoye 2007). The atrocities and pillages that occurred in the areas surrounding Vienna, by contrast, are of only minor interest in these books. There is no comprehensive and complete dataset of municipalities in the areas surrounding Vienna that were exposed to Turkish atrocities and pillages. Lacom (2009), for instance, notes that his dataset of affected municipalities in the state of Lower Austria during Siege II does not claim to be exhaustive. Comprehensive data for the Turkish attacks in 1529 and 1532 are even scarcer.

We therefore self-compiled our own dataset from various sources to identify whether a municipality has a record of 16 th- or 17 th-century Turkish atrocities. We use historical maps, local sources of information, and Wikipedia entries and screened related books. We code a municipality as treated when we find an indication of Turkish attacks, pillages, murders, rapes, or kidnappings. We label a municipality as untreated when we find no references to Turkish attacks.

Table 14 gives an overview of the sources of our dataset. First, we use (historical) maps from Siege II that are provided by Broucek, Hillbrand and Vesely (1983) and Lacom (2009). Second, we rely on local sources that provide information about local history. These are municipal and church chronicles (printed or accessed online), a historical compilation of the museum of the federal state of Lower Austria, and an atlas of the federal state of Burgenland (BurgenlandAtlas). Furthermore, some district administrations provide an overview of the regional history. Note that these local sources may cite each other; i.e., some municipal home pages provide the 
same content as the district home pages and regional sources such as the Burgenland-Atlas (http://www.atlas-burgenland.at/) or the federal state museum of Lower Austria (http://www.museumnoe.at). Third, we browse all the available municipal and church Wikipedia entries. Fourth, we conduct a book search based on the books cited in Section 2.1: Gerhartl (1981, 1983), Gutkas (1973), and Hummelberger (1983). Finally, we perform a Google Books search for all municipalities with no Turkish atrocity record in the other sources mentioned above. We retrieved all the online information between April 01, 2016, and August 20, 2016. Columns (1) and (2) in Table 14 document the number of pillaged municipalities in the course of Siege I and Siege II, respectively, by the source of information. Column (3) depicts the number of municipalities that were pillaged at least once. Column (4) shows the number of municipalities with a single source documenting Turkish atrocities during Siege I or Siege II. The lower rows in Table 14 show the number of affected municipalities and their share in our sample. We ultimately found 341 of 690 municipalities (49.4\%) with a reference for Turkish atrocities and pillages. The coding for 143 of the 690 municipalities (20.4\%) relies on only a single source of information. We conduct robustness checks and apply a fuzzy RD, i.e., instrumental variable approach, to account for a potential measurement bias.

TABLE 14. DOCUMENTATION OF PILLAGED MUNICIPALITIES

\begin{tabular}{|c|c|c|c|c|}
\hline \multirow{2}{*}{ Source of information } & Siege I & Siege II & Siege I and/or Siege II & Single source \\
\hline & $(1)$ & $(2)$ & (3) & $(4)$ \\
\hline Historical maps & - & 167 & 167 & 30 \\
\hline Local sources (e.g., chronicles) & 185 & 211 & 274 & 94 \\
\hline Wikipedia & 91 & 90 & 131 & 9 \\
\hline Book search & 15 & 17 & 31 & 10 \\
\hline Number of pillaged municipalities & 222 & 287 & 341 & 143 \\
\hline Share of total municipalities & 0.316 & 0.416 & 0.494 & 0.207 \\
\hline
\end{tabular}

Notes: The table depicts the sources of municipal-level Turkish atrocity records. These are historical maps, regional sources (e.g., municipal and church chronicles), Wikipedia entries and a book search. Columns (1) and (2) show pillaged municipalities in Siege I and II separately. Column (3) indicates municipalities pillaged in either or both sieges. Column (4) reports the number of municipalities for which we find pillaging information in only a single source of information. 


\section{B. Additional figures and tables}

FIGURE 8. HISTORICAL MEMORIALS (FURTHER EXAMPLES)

\begin{abstract}
A: Official symbols (municipal coat of arms)
\end{abstract}

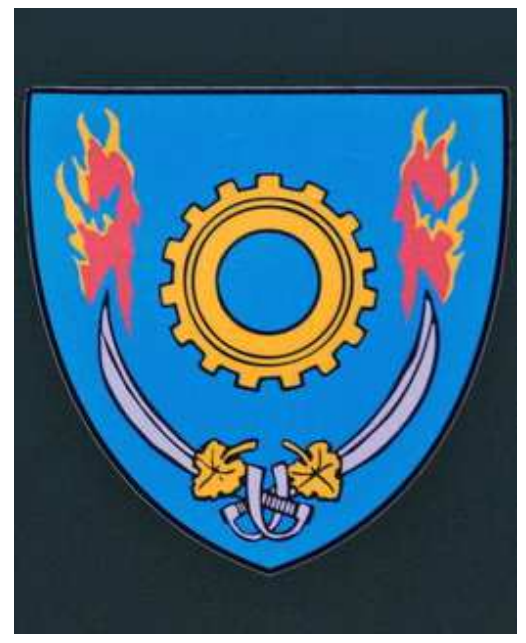

D: Plaques that commemorate Turkish atrocities

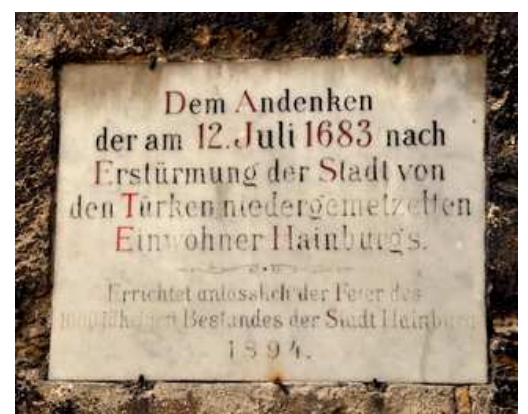

B: Remaining church towers of destroyed municipalities

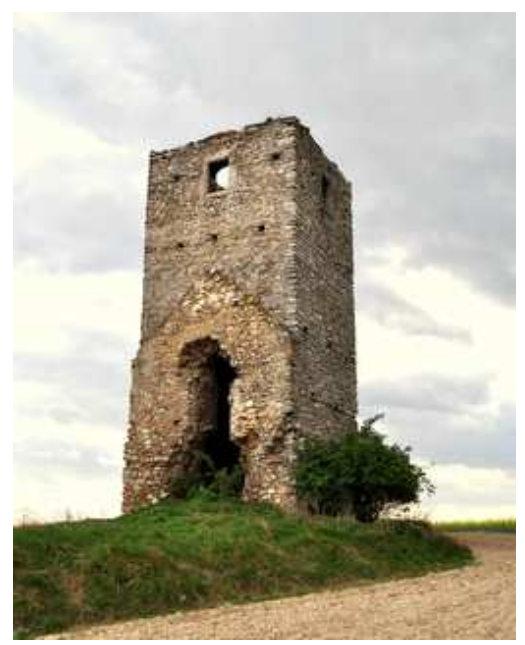

E: Place names (streets, squares, fields)

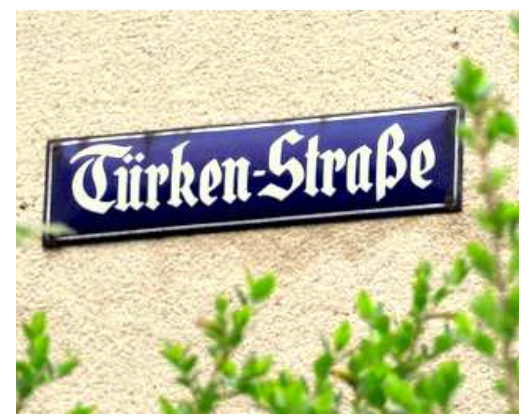

C: Buildings with a direct link to the Turkish invasions

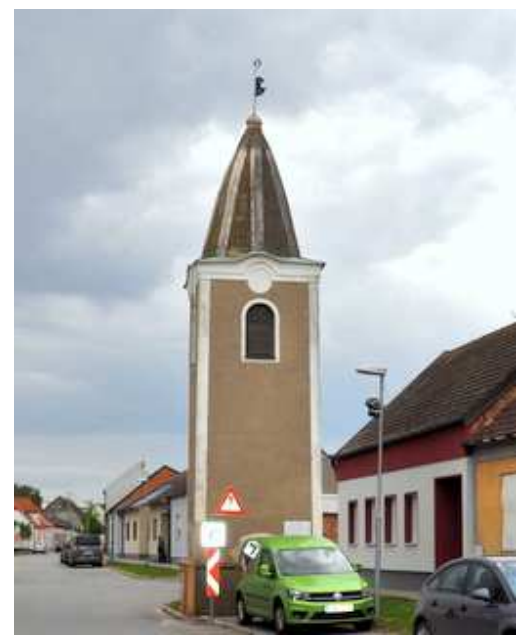

F: Place names (cont.)

Notes: The pictures show further examples of visual memories in Lower Austria and Burgenland. Figure A shows the municipal coat of arms of the municipality of Kottingbrunn. The emblem contains two Turkish swords with flames above them. Figure B shows the ruin of a church tower and the contours of the church nave. The tower is the only remaining building of the village of Lebarn, which was destroyed during Siege I. Figure D shows the "Türkenturm" (Turkish Tower) in the municipality of Pamhagen. The spire of the tower shows the Turkish crescent to commemorate the long gone Turkish presence. Figure D shows a plaque in the city of Hainburg an der Donau. The inscription reads, "In the memory of the inhabitants of the city of Hainburg who were massacred on July 12, 1683, by the Turks during the attack on the city." Figures E and F show a Türkenstrasse (Turkish Street) in the municipality of Zeiselmauer-Wolfpassing and a Türkengasse (Turkish alleyway) in the municipality of Mauerbach as examples of public places, streets, fields and caves that are named after the Turkish invaders. Photo: Christian Ochsner. 
Full sample

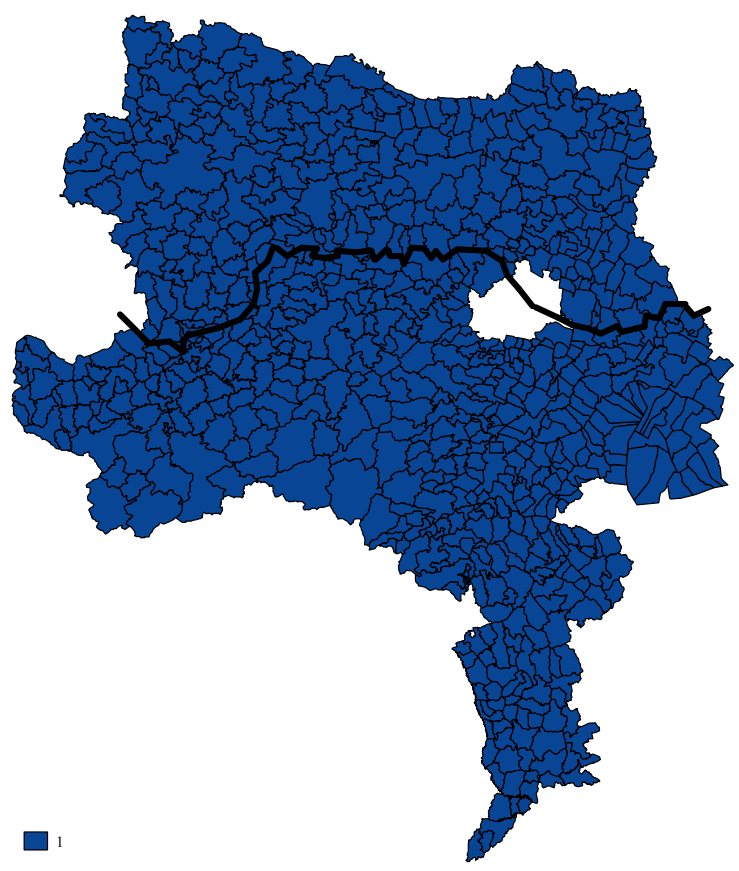

West sample

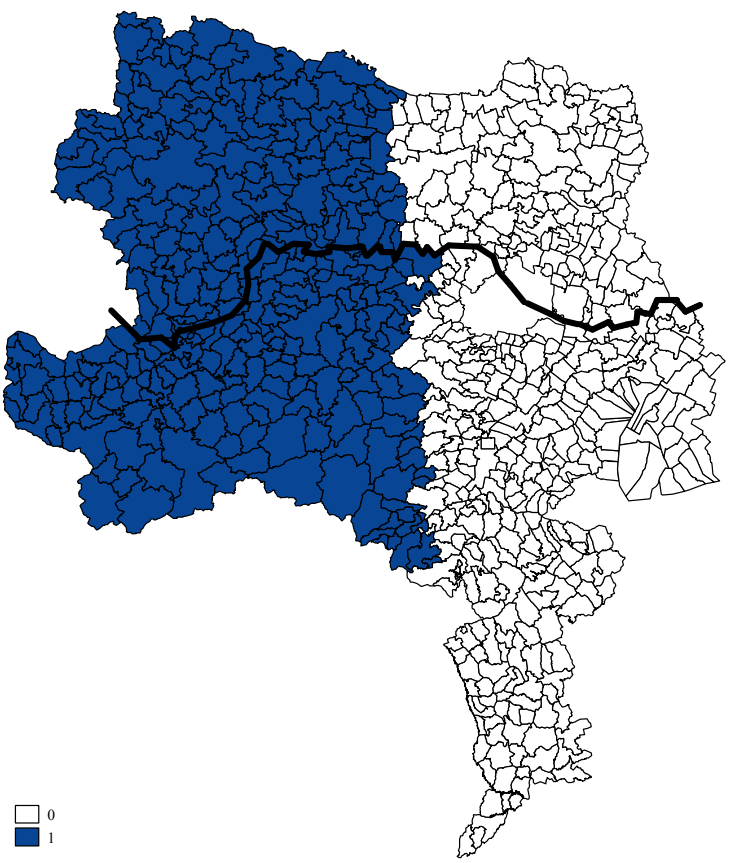

Notes: The maps show municipalities included in the full sample (left-hand side, $n=690$ ) and in the restricted "West sample" west of Vienna (right-hand side, $n=301$ ). The bold line represents the Danube River. The restricted sample includes municipalities of the state of Lower Austria that are located west of longitude $16^{\circ}$. 
FIGURE 10. ForEIGNERS IN AUSTRIA

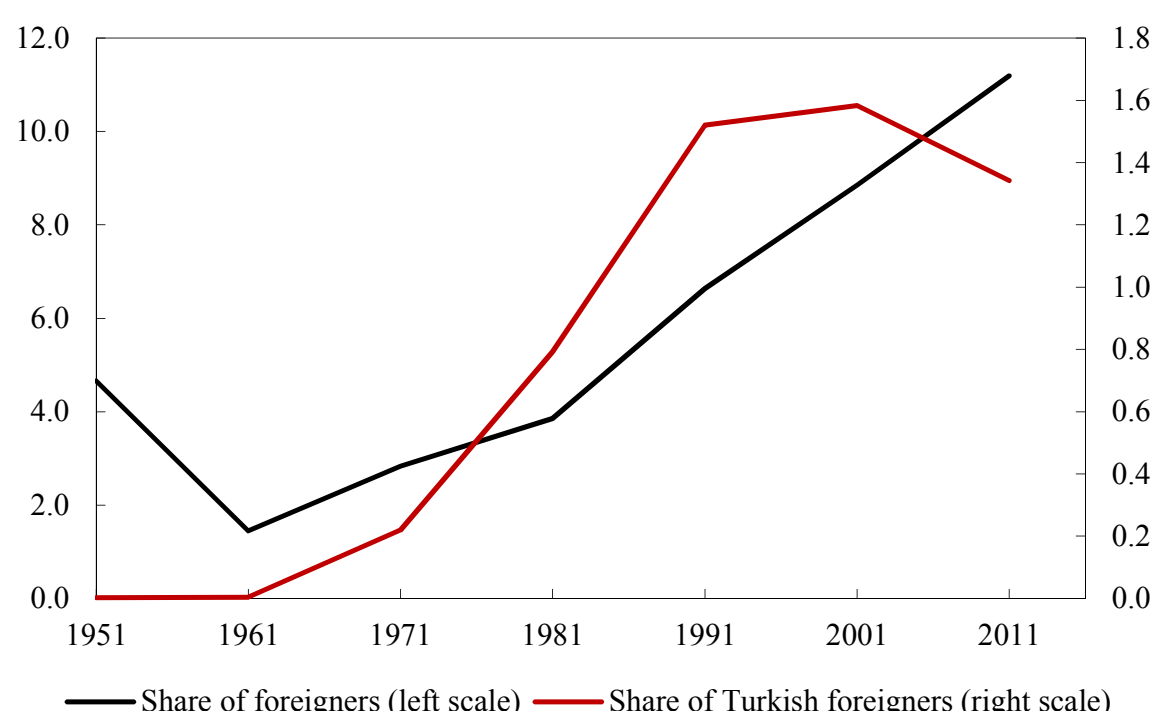

Notes: The figure shows the population share of total foreigners (left scale) and Turkish foreigners (right scale) in Austria since 1951. 
Turkish pillages

(Siege I or II)

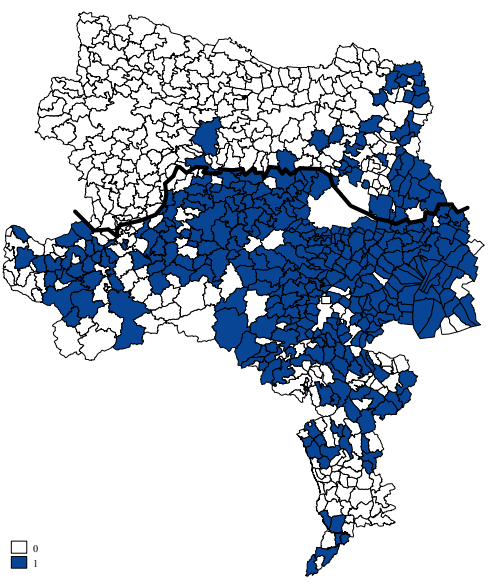

Hungarian pillages

(15th century)

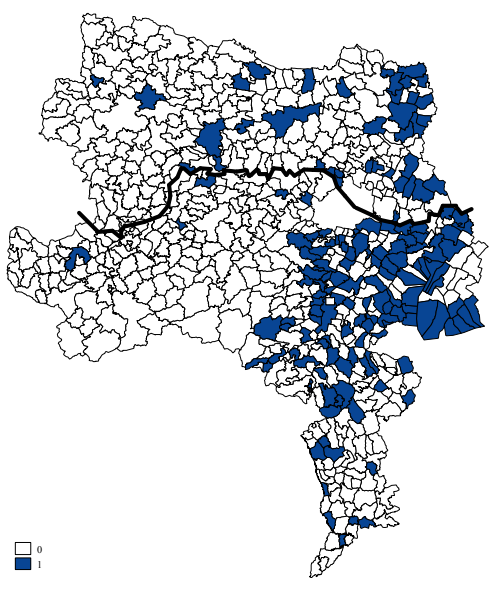

Hussite pillages

$(1420-1434)$

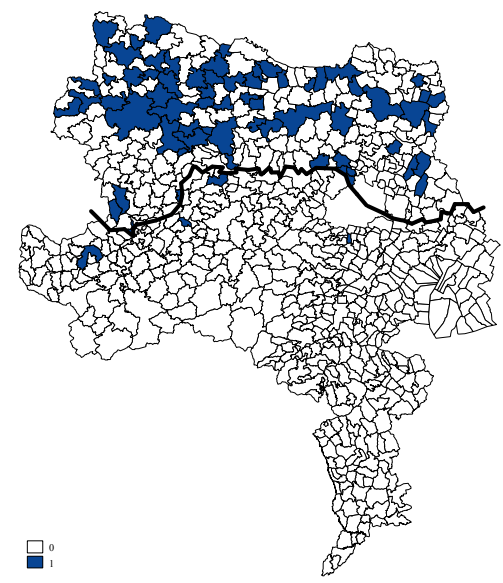

Turkish pillages

(Siege I, 1529 and 1532)

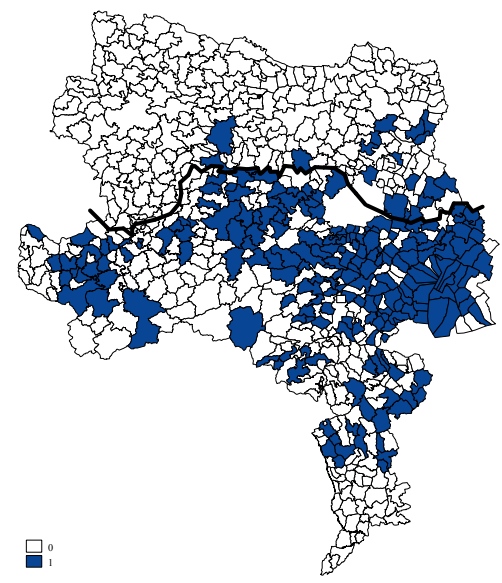

Swedish pillages

(1645/1646)

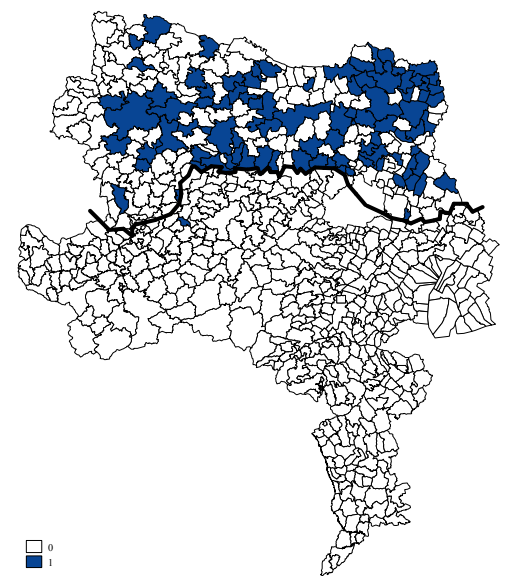

Soviet Army occupation

(1945-1955)

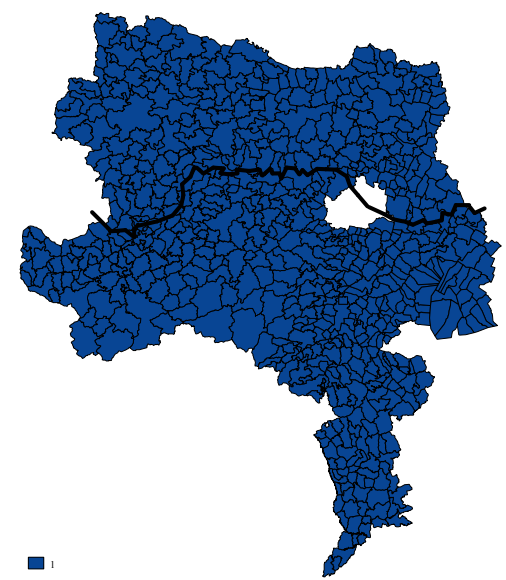

Turkish pillages

(Siege II, 1663/1664 and 1683)

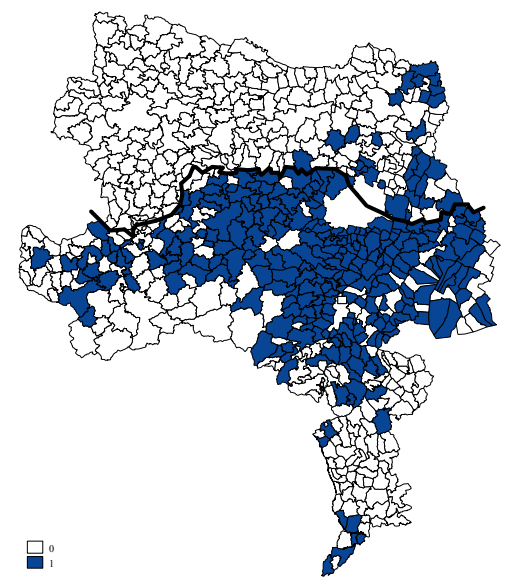

Napoleonic pillages (1805-1809)

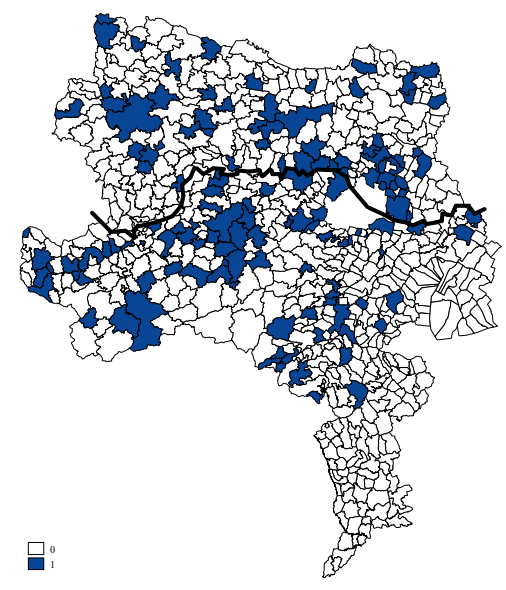

Notes: The maps show municipalities with a record of atrocities or occupation by foreign forces in East Austria at different times. The bold line represents the Danube River. 
TABLE 15. SPATIAL DISCONTINUITIES ACROSS THE DANUBE RIVER

\begin{tabular}{|c|c|c|c|}
\hline \multirow{3}{*}{ West sample $\left(<16.0^{\circ}\right)$} & \multicolumn{3}{|c|}{ Quadratic RD estimate } \\
\hline & 2001 & 2011 & $\begin{array}{l}\text { Difference-in-disconti- } \\
\text { nuities 2001-2011 }\end{array}$ \\
\hline & $(1)$ & $(2)$ & (3) \\
\hline Turkish pillages & $0.384 * * *$ & $0.384 * * *$ & - \\
\hline FPÖ vote share in 2002 and 2013 & $0.961^{* *}$ & $3.797 * * *$ & $2.836^{* * *}$ \\
\hline \multicolumn{4}{|l|}{ Socio-demographics } \\
\hline Electorate $(\log )$ & 0.200 & 0.224 & 0.025 \\
\hline Population share female & -0.063 & 0.255 & 0.192 \\
\hline Population share foreigners & $2.212 * * *$ & $1.228 *$ & -0.983 \\
\hline Population share EU-15 foreigners & -0.041 & -0.067 & -0.026 \\
\hline Population share Turkish foreigners & $1.372 * * *$ & $0.687 * * *$ & -0.685 \\
\hline Population share other foreigners & 0.881 & 0.909 & -0.272 \\
\hline Population share $<20$ years & 0.515 & 0.375 & -0.140 \\
\hline Population share $>65$ years & -0.664 & -0.884 & -0.220 \\
\hline Share agriculture & -1.845 & $-2.226 * * *$ & -0.381 \\
\hline Share industry & $3.396^{* *}$ & 0.902 & -2.494 \\
\hline Population share unemployed & -0.006 & 0.124 & 0.131 \\
\hline Population share Catholics & $-3.510 * *$ & $\mathrm{n} / \mathrm{a}$ & - \\
\hline Population share Protestants & 0.281 & $\mathrm{n} / \mathrm{a}$ & - \\
\hline Population share Muslims & $1757 * * *$ & $\mathrm{n} / \mathrm{a}$ & - \\
\hline \multicolumn{4}{|l|}{ Geography } \\
\hline Distance to Vienna & 8.300 & 8.300 & - \\
\hline Distance to external border & $-7.655 * * *$ & $-7.655 * * *$ & - \\
\hline \multirow[t]{2}{*}{ Distance to highway } & -2.186 & -2.186 & - \\
\hline & \multicolumn{3}{|c|}{ Quadratic RD estimate } \\
\hline \multirow[t]{2}{*}{ East sample $\left(>16.5^{\circ}\right)$} & 2001 & 2011 & $\begin{array}{l}\text { Difference-in-disconti- } \\
\text { nuities 2001-2011 }\end{array}$ \\
\hline & $(1)$ & $(2)$ & (3) \\
\hline Turkish pillages & 0.165 & 0.165 & - \\
\hline FPÖ vote share in 2002 and 2013 & -0.375 & 0.636 & 1.011 \\
\hline
\end{tabular}

Notes: Columns (1) and (2) show the spatial discontinuities in socio-demographic covariates and time-invariant geographic controls across the Danube River for the last census prior to 2001 and the first census after the start of the anti-Turkish campaigning (2011). Discontinuities stem from a quadratic interacted polynomial RD regression using the distance to the Danube River as the running variable with a bandwidth of \pm 50 kilometers to the Danube River. Column (3) depicts the respective difference-in-discontinuity estimates. The upper part of the table shows $\mathrm{RD}$ estimates for the West sample (all municipalities west of $16^{\circ}$ longitude). The lower part of the table shows RD estimates for municipalities located east of Vienna (east of $16.5^{\circ}$ longitude). Significance levels (robust standard errors): $* * * 0.01, * * 0.05, * 0.10$. 
TABLE 16. CONTROL FOR DISTANCE TO VIENNA

\begin{tabular}{|c|c|c|c|c|}
\hline & \multicolumn{4}{|c|}{ FPÖ vote share } \\
\hline & \multicolumn{2}{|c|}{ Full sample } & \multicolumn{2}{|c|}{ West sample } \\
\hline & \multicolumn{2}{|c|}{ OLS } & \multicolumn{2}{|c|}{ OLS } \\
\hline & (1) & (2) & (3) & (4) \\
\hline Turkish pillages $\times$ Post -2005 & $\begin{array}{c}1.285^{* * *} \\
(0.233)\end{array}$ & $\begin{array}{c}0.981 * * * \\
(0.221)\end{array}$ & $\begin{array}{c}2.191 * * * \\
(0.330)\end{array}$ & $\begin{array}{c}1.735^{* * *} \\
(0.316) \\
\end{array}$ \\
\hline Obs. & 13,800 & 13,800 & 6,020 & 6,020 \\
\hline Municipalities & 690 & 690 & 301 & 301 \\
\hline Year fixed effects & Yes & Yes & Yes & Yes \\
\hline Year fixed effects $\times$ Distance to Vienna & Yes & Yes & Yes & Yes \\
\hline Municipality fixed effects & Yes & Yes & Yes & Yes \\
\hline$R$-squared (within) & 0.910 & 0.912 & 0.923 & 0.925 \\
\hline
\end{tabular}

Notes: The dependent variable is the FPÖ vote share at the level of 690 East Austrian municipalities. The full sample consist of all sample municipalities in East Austria $(n=690)$; the "West sample" consists of municipalities west of Vienna $(n=301)$. Significance levels (standard errors clustered at municipality level): $* * * 0.01, * *$ $0.05, * 0.10$. 